\title{
Strada \& Co.: By Appointment to His Majesty the Emperor
}

\subsection{Strada as an Imperial Antiquary and Architect}

Strada's formal appointment at the court of the Emperors Ferdinand I and Maximilian II and the use made of his antiquarian competences by Hans Jakob Fugger and Duke Albrecht $v$ of Bavaria show that these satisfied a need felt by his principal patrons. Strada satisfied this need in the first place by presenting the fruits of his researches, in the form of the libri di disegni documenting numismatic and other topics, many of which have been preserved, and the acquisition of which by his patrons is documented in several cases. All the same it is not likely that these volumes - always paid for separately-were the only or even the most important reason for his employment: note that the two earliest volumes still preserved in Vienna were not commissioned by, but were presented at Strada's own initiative to Ferdinand I and Maximilian II respectively. Strada's initial appointment in Vienna as an architect indicates that his patrons intended to make use of his expertise also in other ways, which are summarized in the next paragraphs.

\subsubsection{Architecture}

In the foregoing chapters, I have presented and commented the sparse occasions in which Strada's activities on behalf of his patrons are documented. These all show that he was employed in the architectural projects of his patrons in an advisory role. The available documents show that in two instances he also provided designs, for the Munich Antiquarium and for some undefined aspect of the Vienna Neugebäude. However, the available documentation does not allow definitive conclusions about Strada's personal participation in the execution of such projects. It seems very unlikely that he had any direct and concrete responsibilities in the actual construction of the architectural commissions at court and in Munich. It is true that Strada appears to claim that role when he wrote to Archduke Ernest in 1579:

So I beseech your Most Serene Highness that, should he wish to employ me in whatever project which involves the arts of design, I can serve hem very well. If Your Highness would choose to have built a beautiful palace 
in the manner of Rome or Naples, in a beautiful style and order of architecture; and would have laid out beautiful gardens, fishponds, fountains and other delights suitable to a great Prince as is Your Highness, I can serve him extremely well, and what I will have had made will be praised by every man of taste. ${ }^{1}$

It is also true that the construction of his own house in Vienna shows that he possessed the necessary competence to realize such a project. Yet even considering the dearth of sources documenting the architectural commissions in Vienna under Ferdinand I and Maximilian II, it seems inconceivable that Strada's direct responsibility for their construction would not have left at least some traces in the archives.

Nevertheless, this does not preclude that Strada functioned as a formal or informal consultant to the architects or master masons who had been charged with their realization, in particular in case of those projects for which he had provided designs. In addition to some general supervision of the transformation of his designs into the construction drawings necessary at the building site, such consultancy would have concerned the correct use of the proportional system and the detailing of the orders, the providing of models for these and for other decorative elements, as well as suggestions as to the materials in which, and the masters by whom these were to be executed. Moreover, Strada's visual-spatial ability, his critical eye and his imagination qualified him to suggest practical considerations related to the intended use of the building, as his design for the Munich Antiquarium makes abundantly clear.

Strada opens his letter to Archduke Ernest with the claim that Maximilian II had kept him continuously at work 'nelle sue fabbriche', that is, in his building projects. This claim cannot have been very much exaggerated, in view of the Archduke's familiarity with the situation in Vienna and his personal acquaintance with Strada, whose son Paolo was a gentleman in his household. This implies that Strada was often involved in the architectural projects at court: apart from the Neugebäude, for which he certainly made a design, the most likely candidates are the Stallburg, the decorative elements of the Hofburg proper, and possibly the earliest plans for what would become the Ernestinische Trakt or Amalienburg. But his principal role would have been in the initial stages of such projects. It consisted of advising the patron about the project in general, suggesting various alternative options and providing models from his own collection and commenting on these: in short helping him to make up his mind what type of architecture to commission. The genesis

1 Doc. 1579-05-00. 

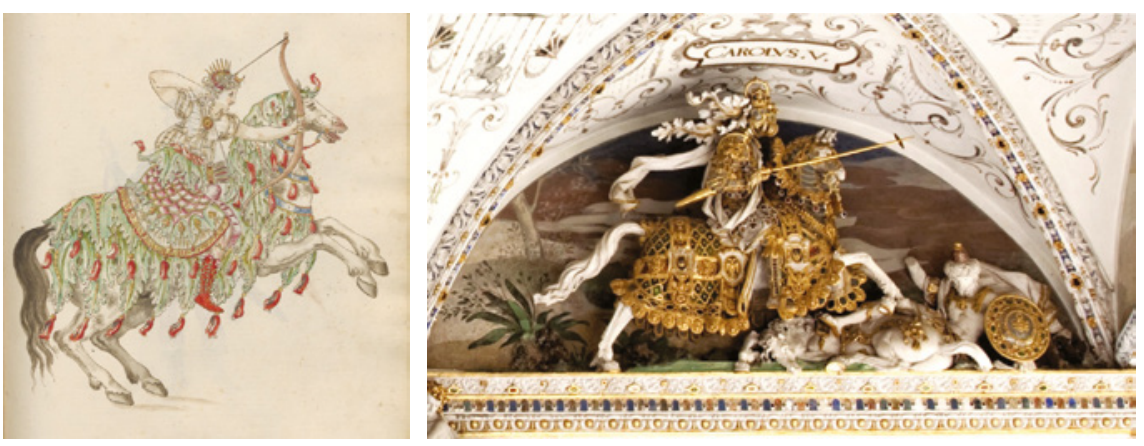

FIGURES 16.1-16.2 Jacopo Strada, Diana, design for a costume for a festival at court, compared with the image of Charles $\mathrm{v}$ in the decoration of the Imperial Chamber at Bučovice, Moravia.

of the Munich Antiquarium shows clearly that this stage could include not just personal consultation and perhaps some preliminary sketches, but also carefully worked-out designs. Formal responsibility for the negotiations with the architects, master masons or contractors who were to execute the projects remained with other court-officials, such as the Bausuperintendent, but it is likely that Strada occasionally advised the patron on their selection, and afterwards coached them as to the aspects of his own expertise. These included the correct use of the orders as well as practical problems: thus for the Antiquarium Strada advised about the form and the technical possibilities (in stone or wood) for the window frames and about the ideal material for the plaques for the inscriptions and where to obtain it. He derived his authority to informally supervise the executive architects and the various artisans employed from his own formal status as Imperial Architect, his specific, unrivalled expertise, and the fact that he acted as a representative or an agent of the patron himself.

\subsubsection{Designs for Festivals and Decorative Ensembles—and Their Production}

The information about the organisation of the execution of decorative ensembles in the Imperial residences, and for the ephemeral decorations and costumes for festivities, pageants and ceremonies, is as scanty as that about the architectural projects. We know that Strada was involved in an unspecified role in the genesis of the tombs of the Emperors Maximilian I in Innsbruck and Ferdinand I in Prague: here he doubtless contributed advice on imperial iconography, his own antiquarian specialism, but he was probably also consulted on the artistic aspects of these important dynastic commissions. In the designs 
he made for costumes for court festivals discussed in chapter 4.3.5, a number of which have been preserved, he certainly combined his iconographical expertise and artistic prowess [Fig. 16.1 and above, Figs. 4.13-4.22]. This in turn strongly suggests that he provided similar combined services for the interior decoration of the Imperial residences, for instance the ceiling of the Goldene Saal in the Innsbruck Hofburg, where his participation is documented, but also on other locations. Perhaps the richly decorated spaces in the towers of the Neugebäude may have been among these, as is suggested by their connection with the slightly later set of rooms in Bučovice, with which Strada can be linked [Fig. 16.2].

In all these cases it is impossible to say with any certainty what exactly his interventions may have been. These were probably wide-ranging: from a simple comment on the proposal of a fellow artist or the estimate of his finished work, to a careful discussion of a planned commission and its iconography with the patron and members of his entourage, when he would illustrate his oral advice by showing relevant models from his Musaeum. Then they would include advice as to the selection of the artists to execute the commission, their coaching and/or the supervising of their work, as well as providing his own sketches or even worked out designs. This is the more probable in view of the fact that Strada basically thought in images, so would naturally have illustrated his points of view with quick sketches. He explicitly stressed the great value he attached to such visual means of communication in his letter to Adam von Dietrichstein discussed in Chapter 11.6. The immense collection of visual documentation he brought together demonstrates that he practised as he preached. The numerous drawings or 'inventions' from Strada's studio that have been preserved confirm his lively visual imagination, and make clear that, though he was no great artist, he was a perfectly competent designer. Taken in all, the evidence linking Strada's direct or indirect involvement in such projects at court is not abundant; but it is certainly amply sufficient not to exclude him without good grounds, when attributing work done at court or in its perifery.

In contrast to the architectural projects, where Strada never was directly responsible for the execution of the projects to which he had contributed designs, at least on occasion he may have been given the responsibility both to organize and to supervise the execution of decorative schemes and of festival costumes and decorations. His own artistic training guaranteed his competence as to its artisanal aspects, whereas the big documentary projects he had had in hand in Rome in the 1550s make clear that he knew how to handle complex projects involving many individual artists. His wide network allowed him quickly to find the right man for each aspect of a given project. This was particularly useful in the manufacture of costumes and 
decorations for court festivals, when a huge number of disparate objects had to be produced in a quite brief time-span. Four things were indispensable to make this a success:

- a perfect comprehension of the patron's wishes and intentions

- a close collaboration and mutual understanding between the courtiers, the literati—such as Giovanni Battista Fonteo-, the musicians-such as Philips de Monte-and the senior artists-such as Giuseppe Arcimboldo, Francesco Terzio, Pietro Ferrabosco, Matthias Manmacher, and Strada himself-who had been commissioned to provide the concepts, the texts, the scores, and the designs

- a careful and detailed planning

- and finally a careful coordination and close supervision of the many artists and artisans who were to convert these 'inventions' into reality.

It is probably no coincidence that just these aspects are stressed in Strada's letter to Archduke Ferdinand II of Tirol, in which he offered to undertake the coordination and supervision of the huge silver table fountain representing Adam and Eve in Paradise which the Archduke had commissioned from Strada's friend and colleague Wenzel Jamnitzer:

And even to make a design for such a work, one needs to know the mind of Your Excellency, and also the size [of the planned work], because it has to be arranged with judgement, and according to Scripture, and all parts [should be] made in due proportion. And even then it would be difficult to show in a drawing, because it will take up so much space. To understand it well, one should rather make a [three-dimensional] model or master plan ['modello ovvero patrone'] as one does when one wants to build a palace, for the use of the masters to be employed in the project.<...> And it would also be necessary to have a superintendent ['sopra capo'] who well understood the work, so that he could guide the masters [in their work], otherwise the expenses of the work would soar, and the chance would be that [the result] might not even please Your Excellency. ${ }^{2}$

Neither is it a coincidence that, as at the beginning of his career at the Imperial court, at its end he should imagine a quite similar role when he offered his service to Archduke Ernest: the relevant passage as quoted earlier continues:

I can also serve in having made inventions for masques, tourneys and jousts and other beautiful things that may occur to your Highness. ${ }^{3}$

2 Doc. 1556-12-22.

3 Doc. 1579-05-00. 
The tell-tall phrases in this letter are 'quello ch'io farò fare'; 'what I will have had made will be praised by every man of taste', and 'far fare': 'I can also serve in having made inventions for masques $<\ldots\rangle$ '. Both passages imply that Strada offered his services not, or not exclusively, in his role as an artist, but that he proposed to direct specific projects on behalf of the patron, acting as an agent realizing the patron's specific ambition. The documented instances suggest that in such projects, according to circumstance, Strada was able to act as the director or the producer of such entertainments. The staging of a court masque, joust or ceremony, the creation of sumptuous, complex decorative schemes or the realisation of ambitious works such as an Imperial tomb, or Jamnitzer's silver fountains for Archduke Ferdinand II of Tirol and Emperor Maximilian II, involved a similar distribution of tasks, not all of which are necessarily mentioned in the financial records.

Some such division of tasks is implied in a note in a manuscript programme for festivals organized in 1571 to celebrate the wedding of Archduke Charles and Maria of Bavaria, which indicates Giuseppe Arcimboldo as its 'fabricator' and Giovanni Battista Fonteo as its 'coordinator.4 Strada's existing festival designs suggest that he sometimes acted as a 'fabricator' or a (co)director, contributing to the iconography of a masque and designing its costumes; while at other times he may have acted as its 'coordinator' or producer: selecting and organizing the artists and artisans who were to realise the actual objects needed, the designs of which were provided by some other 'fabricator', such as Giuseppe Arcimboldo. And occasionally he may have combined both functions: the phrasing of Emilio Stanghellino's remark to the Duke of Mantua about the role of 'nostro Strada Mantovano' in the fabrication of the costumes for the jousts on the occasion of Rudolf II's coronation as king of Hungary strongly suggests that he both designed them and organized their manufacture. Stanghellino even appears to imply that that was a natural function of the 'antiquario.' ${ }^{5}$

Altogether there is sufficient evidence to conclude that Strada at least occasionally was given the charge - as Stanghellino phrased it - to organize and supervise the realization of decorations and costumes for festivals at court, and that this was one of the tasks implied in his function as Imperial Antiquary. However, even when this task may have come natural to the antiquary, given his expertise, it was not his formal or exclusive responsibility: other court

4 Cited by Thomas DaCosta Kaufmann in Arcimboldo 1526-1593, 2007 p. 265, cat. nr. VII.35; the precise significance of these terms as used in this instance remains to be clarified.

5 Doc. 1572-09-03: 'Il Strada nostro mantovano, come antiquario, ha havuto carico di far fare gli habiti, girelli e sopraveste per le giostre delli serenissimi principi, quali vanno fatti all'uso dell'armatura antica, ma riusciranno vaghi et ricchi assai, essendo gli drappi d'oro et argento fini, con pocchissima seta, guarniti di bellissimi riccami et frangie d'oro riportate.' 
artists, Arcimboldo in the first place, were likewise commissioned to conceive, design and supervise such festivals.

\subsection{Strada's Role as an Agent}

\subsubsection{Agent and Broker?}

In such cases the initial commission was probably informally given by the Emperor himself, and Strada can thus be considered to act as an agent of his patron, though in practice he was probably asked to report to the court dignitary ultimately responsible, for instance the Master of the Horse (Oberststallmeister). He thus functioned as an intermediary between the patron or his substitute and the artists and craftsmen who were doing the actual work (as well as the courtiers who were expected to figure in the festival, who had some say in what they were going to wear, having to pay for it). In view of the huge amount of work to be done in a very brief time, Strada must have collaborated closely with some or all of the other senior artists at court, such as Arcimboldo, Terzio, Manmacher and Ferrabosco. We know from Van Mander that travelling artists - such as Bartholomeus Spranger, Hans Mont and Van Mander himself-were also recruited. In a similar way, he would have acted as an intermediary between the Emperor and the artists employed in the decoration of spaces in the Hofburg, the Neugebäude, or other Imperial residences. As in the architectural projects, he would derive his authority for such supervision from the Emperor's brief, his official position as Imperial Architect, and his undoubted expertise.

Such supervision came naturally to Strada, because of his familiarity with Giulio Romano's role as general superintendent of all architectural and artistic endeavour at Mantua. To some extent Giulio's example may have furnished Strada with a model for his own career: his construction of a prestigious house, serving as a conscious advertisement of its builder's competence and expertise, is the most evident example. On the other hand, it is equally evident that neither in Vienna nor in Munich Strada ever aspired to anything approaching Giulio's central position in the artistic, architectural and infrastructural policies of the Gonzaga state. This was partly due to the different circumstances: as an Italian Strada was probably more of an outsider in Vienna than Giulio was in Mantua. ${ }^{6}$ The functioning of the multinational Imperial court was not comparable to that of a small homogeneous state as Mantua; moreover the

6 In a letter to Jacopo Dani, Strada attributes a lack of collaboration by the local authorities partly to the fact 'ch'io non sono tedesco' (Doc. 1576-06-16). 
Emperor was probably less interested in the extreme visual splendour aspired to by Francesco and Federico Gonzaga. But it was also due to Strada's own preferences: Giulio's antiquarian studies, however serious, were basically engaged in to serve his artistic ends; whereas Strada considered the artistic use that he could make of them as a spin-off, perhaps as a justification for his more purely antiquarian pursuits. He engaged in these for their own sake, as the big proportion of his time, energy and patrimony he invested in them make clear.

When Strada represented his patron's interest in supervising such projects in Vienna itself, his function did not fundamentally differ from that of any other court official charged with a particular task. But Strada also represented his patrons' interests abroad, acting as an agent acquiring books, antiquities and works of art. Because this aspect of his services to his patrons involved travel, for which expenses were paid and which gave rise to consultative correspondence, it is much better documented than what he did for them when at home. Even so, this is only true for Strada's trips to Venice in 1567-1569, when he was explicitly commissioned by Duke Albrecht $\mathrm{v}$ of Bavaria to buy antiquities and works of art: there can be little doubt that his acquisition of the Loredan collection for Munich was the most important transaction of his career. ${ }^{7}$ But it is only in the margin of this huge project that we are informed about the wide range of other activities - they are described in chapter 13 - that Strada engaged in during these trips, acting both on behalf of his known patrons as well as for himself and perhaps for other, as yet anonymous patrons.

We know that Strada was an indefatigable traveller, and in the 1560 s he made at least two other trips to Italy before being sent to Venice by Duke Albrecht; he also regularly travelled in Germany (to Munich, to Augsburg, to the Frankfurt book fair) and to Prague. During such travels he doubtless engaged in similar activities as those documented for his trips to Venice: picking up antiquities, works of art, books and other objects for which his patrons had expressed an interest, or which he thought might appeal to them. In addition, he may have scouted for talent: if he signalled a well-known troupe of Italian commedia dell'arte actors to Maximilian II, it is quite likely that he would have done the same when meeting architects and artists whom he thought might be useful in Vienna or Munich. He certainly acted as an intermediary between Titian and Duke Albrecht v and Hans Jakob Fugger. He drew Maximilian II's

7 It is in this context that Strada described himself as an agent of the Duke, in his defence in the Senate of Venice against accusations borught against him by Andrea Loredan: 'Io son gentilhuomo di S. M. e son al presente agente dl S.mo Ducha in questo negotio, come fanno le mie lettere testimonio,' 'Risposta ala Callumnia', Doc. 1568-oo-oo, fol. 36/134v. 
attention to Titian's 'poesie' and perhaps to Jacopo and Marietta Tintoretto, as is suggested in Chapter 12.5.3. When Maximilian II requested Veit von Dornberg, his envoy in Venice, to go and find out more about the sculptor Alessandro Vittoria and the architect or master mason Jacometto Tagliapietra, he told Dornberg their exact addresses. Doubtless the Emperor had this detailed information from Strada, who had just returned from Venice, where he had been employing Vittoria in some project of his own. ${ }^{8}$ In fact, to provide such information must have been one of Strada's tasks at court, and he may have recommended certain artists, or even have been instrumental in their employment, on other occasions. Therefore, the arrival of some of the artists at court may have been due to their earlier acquaintance with Strada, or a connection through one of his correspondents. A possible example is Giulio Licinio, who left Venice to try his luck among the Augsburg patricians shortly after Strada's stay in Venice in 1556 , and then soon followed in his footsteps to the Imperial court.

The role and function - explicitly not the 'profession' —of agents such as Strada have been the subjects of the research project, 'Double Agents: Cultural and Political Brokerage in Early Modern Europe. ${ }^{9}$ Both Strada's activities and his personal characteristics largely conform to the profile of the archetypal agent as formulated by Marika Keblusek: 'To function successfully as an agent depended first and foremost on one's ability to build and maintain two key relationships: with one's employer-or patron —on the one hand, and with one's network(s) on the other'. Such capacity was dependent on the agent's background, his social standing, his education, his geographical roots, his religious persuasion and, not least, his character. Keblusek quotes David Howarth's list of the 'general talents' an agent needed to have: 'stamina, organisational and social skills, and a command of foreign languages. These, precisely, were qualities without which no agent could survive<... >. Other qualifications were a favourable geographical position and/ or easy mobility: many of the agents of the type shared an immigrant background, or at least were accustomed to travel. ${ }^{10}$ These were all qualities that Strada possessed. Moreover, he succeeded in obtaining the fullest confidence of his patrons-a confidence expressed in the many favours they granted him —and, at least in the case of Hans Jakob Fugger, a considerable degree of intimacy and even friendship. XLXIX, Regest nr. 8807 .

9 It results published in Cools/ Keblusek/ Noldus 2006 and Keblusek/ Noldus 2011.

10 Keblusek 2006, p. 10-12. 


\subsubsection{Double Agent... Or Rather Single-minded?}

A further quality such agents shared, was a high degree of versatility or adaptability to sometimes quite divergent tasks: tasks for which they were not necessarily formally qualified, but in which they could be employed all the same. It is in this sense, as well as in the more current one, that such agents often were 'double' agents: thus secretaries, merchants, artists and soldiers doubled as political informers (or even as outright spies), while academics and diplomats chased after books, antiquities, works of arts and doubled as talent spotters as well. Tasks they were expected to shoulder, not necessarily because they were the right man for the job, but rather because they happened to be in the right place at the right time: that is, they were seldom employed because of their proper specialism. ${ }^{11}$

Strada disposed of a wide field of interest and certainly was versatile and adaptable: doubtless, he occasionally will have served his patrons in fields beyond his own expertise. He must have passed on much information he heard on his travels to his patrons in Munich and Vienna, or to the relevant officials at their courts. Occasionally he may have carried confidential dispatches to the rulers of places he was scheduled to visit. However, any trusted courtier departing on, or returning from a voyage would have done as much, so this does not set Strada apart. In any case there are only two documented instances in which Strada was explicitly asked for a service unconnected with his own specialist expertise. In the autumn of 1565 he lobbied with the Vizereichskanzler Johann Baptist Weber on behalf of Carlo Maffei, 'maestro di camera' of Guglielmo Gonzaga, presenting a letter of recommendation from the Duke and explaining Maffei's business. ${ }^{12}$ In December ${ }^{1569}$ he provided Duke Guglielmo of Mantua with information about grain prices in Munich, which he must have obtained from correspondents in that town, probably from Fugger himself. ${ }^{13}$ Neither instance is representative, because Strada was not in Duke Guglielmo's employ. He rendered his service both in return for patronage received earlierthe Duke's help in Strada's Mantuan projects and the benefice conferred on his

\footnotetext{
11 Ibidem, p. 11.

12 Docs. 1565-10-15 and 1565-10-23. It is obvious that one hand washed the other, because in return Maffei lobbied with the Duke to concede a benefice in Mantua cathedral to Strada's son Paolo.

13 Doc. 1569-11-05; The Mantuan ambassador had asked for this information, but Strada preferred to communicate it directly to the Duke in person. Unfortunately the published version (JdKS 16, 1895, II, Regest nr. 13998) leaves out the actual information Strada had obtained; I have not been able to find the original document, which is not included in Venturini 2002. In at least five letters to Duke Guglielmo — and only to him—does Strada indicate himself as the Duke's 'efitionatissimo servidore et vasallo' (cf. above, Ch. 13.8.2, n. 125).
} 
son Paolo - and as a loyal subject or 'vasallo' of his liege lord: as such Strada habitually indicated himself in his letters to Duke Guglielmo. So it must be concluded that, in contrast to most of the 'double agents' studied in the eponymous project, Strada was employed primarily or even exclusively by virtue of his professional accomplishments and his specialist expertise.

Such an appointment for specialized services is not unusual in itself. By its nature, the appointment is similar to that of a court chaplain, a court physician, a musician, an architect or a court-painter: all functionaries expected to exert their particular specialism on behalf of their patron. It is just that Strada's specialism is rather more unusual; but even then his position in Vienna can be compared to that of other scholars or scientists at court, such as Carolus Clusius, appointed for his specialist knowledge of botany, or Joannes Sambucus, appointed for his literary talent and historical knowledge. Just like Strada, Clusius travelled and used his network to collect rarities for his patron, in his case of a botanical nature. Such instances provide the perfect illustration of Samuel Quiccheberg's advice to princes and great noblemen desirous to build up a universal collection: these should employ 'ingenious men which they send to various countries to look for wonderful things [rerum miraculosarum]'. In fact, Strada's activities on behalf of Hans Jakob Fugger, Quiccheberg and Strada's common patron, may have provided the concrete example on which Quiccheberg based this 'admonition.' ${ }^{14}$ Both in Munich and in Vienna Strada was employed for his expert knowledge of antiquities, for his competence in translating these into contemporary works of art, as well as for his experience and his network in these two fields, which covered half of Europe.

\subsection{Strada as an Independent Agent}

\subsubsection{No Full-time Job}

In Munich, Strada's situation was relatively well defined, and it is well documented: he was engaged for a limited time, for a particular job, and with something of a fixed budget. His position in Vienna is less clearly defined: formally, it consisted of two components. The first of these was his job as an architect: as we have seen, this was mostly of a consultative character. Except for the albums of numismatic drawings he provided, this was also the case for Strada's second job as an antiquary. Because he gave such advice in person to his

14 'Optimates in his colligendes decebit habere homines ingeniosos quos ad diversas regionum mittant inquirendarum rerum miraculosarum gratia' (Quiccheberg 1565, D ii, a; Quiccheberg/Roth 2000, p. 92). 
patron, the Emperor, to his officials, and to the artists employed, neither the extent nor the exact substance of this task is documented.

Its extent should not be underestimated: there is sufficient reason to assume that it was more ample than the few documented instances would have us believe. As to their substance, the scope of Strada's interventions, it is difficult to determine to what type of projects Strada was expected to contribute: did he have a finger in every pie, or was his advice only asked in connection with a limited, more or less clearly defined group of artistic endeavours? Though this question cannot be answered conclusively, it seems that his advice would have addressed either one or both of two principal aspects. The first aspect directly related to Strada's antiquarian erudition, and involved providing iconographic information: examples are the tomb of Ferdinand I in Prague and the costumes and decoration 'all'antica' for certain court-festivals. The second aspect involved giving more general artistic advice, for which Strada was qualified by his cosmopolitan cultural knowledge and his first-hand experience of the most advanced examples of the new style in Italy. In practice these two aspects often largely overlapped; it was Strada's capacity to integrate these aspects that made him particularly attractive to his employers.

Yet one should be equally wary of overestimating as of underestimating Strada's tasks. There can be no doubt that Strada should not be considered as a minor court-official, earning his daily bread by his modest exertions for his Imperial patron, under the day-to-day supervision of the department of one of the higher ranking courtiers, such as the Oberstkämmerer. He certainly was not the 'Aufseher auf die Kunstkammer' that Schlager held him to be, doubtless because of a misconception of Strada's use of the term Antiquarius. If such had been the case, Strada would have been inscribed in the Hofstaat as a regular member of the Department of the Chamber, which was responsible for the maintenance of the movables in the Imperial residence. Instead, he was mentioned among a few 'Diener von Haus aus', implying that, even though he ranked with the other 'gentiluomini', a day-to-day attendance at court was not part of his duties.

Moreover, Strada's combined remuneration of three hundred Gulden annually (which was almost always in arrears) bears no proportion to the expense and splendour of the house he built himself, at a cost he estimated at up to twelve thousand Gulden. An aristocratic residence built ex novo in the best part of town, it made him the neighbour of those scions of Austria's feudal nobility that filled the higher echelons of the Imperial court. We do not know what Strada, as eldest son, inherited from his father: the fact that he began building his house in Vienna almost immediately after Giovanni Rinaldo's death, suggests that it may have been substantial. Part of his wealth may be explained by the generous patronage of Hans Jakob Fugger and the Duke of Bavaria-if he was paid the extraordinary sum of a ducat for each sheet of his Magnum ac 
Novum Opus, as appears to have been the case, this alone would have brought him in close to 9,0oo ducats. Yet even this would not have sufficed to cover the cost of his aristocratic style of life, and his huge investments in his collection and in his publishing projects. If we had Strada's private accounts, we could draw more certain conclusions. But even the little we do know strongly suggests that — besides being an artist, a scholar and a courtier — Strada was a merchant: a merchant trading on the level of the Nuremberg patricians and the Nuremberg bankers of Italian origin with whom he rubbed shoulders, though of course not on the grand scale of the Fuggers. Nevertheless, his intimacy with Hans Jakob Fugger suggests that they were more than just patron and client: Fugger actually addresses Strada as 'compare mio', which implies a high level of mutual confidence, and their relationship may well have been that of business relations, as well as that of friends sharing many interests.

So Strada's salaries at court should be considered as retainer fees, rather than as the remuneration for a full-time job. This implies that Ferdinand I and Maximilian II were eager to have Strada at their disposal, but that he was left free to earn money in other ways. In fact, as we have seen, he was given ample opportunity to work for other patrons, such as the Duke of Bavaria. Moreover, Ferdinand I and Maximilian II not only allowed him more than enough time to invest in his business-ventures, but also explicitly supported his ambitious editorial projects. ${ }^{15}$

\subsubsection{By Appointment to His Majesty the Emperor, Purveyor of Erudite Counsel... and Luxury Goods?}

This indicates that the retainer fee was also motivated by the Emperor's wish to secure the presence of Strada's collection, his workshop, and his enterprise in the immediate vicinity of the court. Such seems to have been Strada's understanding from the start: when in February 1558 he asked Ferdinand I to be accepted among his 'virtuosi' he tactfully suggested that he would be bringing his collection and workshop with him:

I believe Your Majesty has appreciated, and also in its effects, my ardent wish to serve the most powerful House of Austria, and in what veneration and honour I hold it, having brought together various beautiful and rare things to serve it, not without great expense, and of this Your Majesty has seen a large part, as has the most illustrious and reverend Lord, the Cardinal of Augsburg. ${ }^{16}$

\footnotetext{
15 Cf. Chs. 4.4 and 14.6.

16 'Creddo che la Maestà Vostra habbia visto in bona parte, et anche con gli efetti il mio bon volere ch'io tengo di servir la casa potentissima d'Austria, et in quanta veneration et honor
} 
He explicitly promised the King to do his utmost 'per farmi honore', in order to enhance the splendour of Ferdinand's court, an implication that is repeated in Strada's accompanying letter to Ferdinand's first chamberlain, Martín de Guzmán:

$<\ldots>$ certainly, wherever I will find myself, I will always be the most affectionate [servant] of the House of Austria, and will expend my property and my honour for its sake whenever I can. ${ }^{17}$

It also helps to explain why, when Strada was building his grand new house in order to 'farmi honore', the Emperor allowed him the use of materials from the Imperial building works, recognizing that Strada's enterprise would contribute to the splendour of Vienna and his court. He was not mistaken in this, witness the praise it received from high-placed visitors such as the Duke of Ferrara and the diplomat Hubert Languet.

All this strongly suggests that Strada's independent activities as such were among the reasons the Emperors appreciated his service at their court. They not only expected to make use of Strada's expertise in their own projects, but also recognized that his presence in Vienna and that of the small but splendid cultural centre, his Musaeum, would - at little cost to themselves-stimulate erudite and artistic endeavour in general, and thus increase both the 'tone' and the renown of their court.

\section{4 'Ex Musaeo Iacobi de Strada': Study, Studio, Workshop, Office, Showroom}

\subsubsection{Museum, Studio, Workshop}

Strada's Musaeum was essential to his ambition to document, study and exploit the legacy of Antiquity, and to disseminate its best qualities as exemplified in the most outstanding works of contemporary art. The importance he attached to his library and collection is already evident in the title page of the

la tengo, con aver messo insieme varie cose belle et rare per servirla, non senza spesa, e di questo la Maestà Vostra ne a visto bona parte et ancora lo Illustrissimo et Reverendissimo Signor il Signor Cardinale di Augusta [= Otto Truchsess von Waldburg, CardinalArchbishop of Augsburg]', Jacopo Strada to Ferdinand I, King of the Romans, Nuremberg, 21 Februari 1558, Vienna (Doc. 1558-02-21(a)).

17 'Et certo dov'io sarò et mi trovarò, sempre sarò efitionatissimo a la Casa d'Austria, et spenderò la robba et l'honore per Lei dove potrò', Jacopo Strada to Martín de Guzmán, Nuremberg, 21 February 1558 (Doc. 1558-02-21(b)). 
Epitome thesauri antiquitatum of 1553, pointedly presented 'Ex Musaeo Iacobi de Strada, a phrase which he would repeat in each of the books published at his expense, and which he more or less invented. ${ }^{18}$ In view of Strada's specific interests, a possible source of inspiration may have been the title page of an edition, printed in Venice in 1546, of Paolo Giovio's lives of the illustrious men whose images were included in the well-known portrait collection housed in Giovio's villa at Como. ${ }^{19}$ In view of its function, the term 'Museion' as used in Erasmus' Colloquia familiaria for a library annex small but refined collection is an even more likely source. As Renate von Busch has shown, the term was already used in this sense by Johannes Cuspinianus in 1515. In the brief biography of Melanchton published shortly after his death the term 'Musaeum' is used in the same sense. ${ }^{20}$ Strada's colleague, the Paduan antiquary Alessandro Maggi (1503-1587) used the term to indicate the library and collection of antiquities in the Paduan residence of Cardinal Pietro Bembo. ${ }^{21}$ Strada doubtless was aware of the status such illustrious examples conferred, but he may also have been inspired by the far more practical indication 'Ex officina'- 'out of the workshop' - used on their title pages by many printers: Strada's 'Ex musaeo' could then be read as 'out of the study', distinguishing his intellectual effort from the printer's manual craft.

Certainly, for Strada his 'Musaeum' functioned as both storehouse, library, scholar's study and artist's studio. It was here he collected and organized his materials. It was here he elaborated these in new products: the libri di disegni he prepared for his patrons, the designs for costumes and apparel he provided for their festivities, and the verbal advice, sketches and designs and iconographical suggestions he contributed to the architecture, decoration and

18 The French edition of Strada's Epitome has 'de l'estude de Iaques de Strada'. The only two earlier examples I readily found were both German, a set of sermons: Friedrich Nausea, De reformanda ecclesia<... >oratio, Mainz [Schoeffer], 1527 (unnumbered pages, epigraph to the fifth item included: 'ex Musaeo nostro'); and a one-page academic pamphlet: Christophorus Ostvaldus Foropaganus, Bene hunc disputandi morem, qui multas hodie possidet Academias.: 'Ex Musaeo nostro Ingolstadij die 5. Idus Augusti Anno<...>1542'. These two examples come from a quick search in Google Books, which resulted in 22 hits, the other 20 of which were references to various editions of Strada's works. This was not complete (Strada's 1575 editions of Caesar and of Serlio's Settimo Libro did not appear, though both carry the phrase on their title page as well). After 1553 the phrase becomes slightly more common.

19 Paolo Giovio, Elogia veris clarorum virorum imaginibus apposita: quae in Museo Ioviano<... >spectantur, Venice [Tramezzini] 1546.

20 Quoted in Liebenwein 1977, p. 231, n. 14; Von Busch 1973, pp. 66 ff.; Brevis narratio exponens, quo fine vitam in terris suam lauserit reverendus vir D. Philipus Melanthon, Wittenberg 1560, passim (unnumbered pages). 
furnishing of their residences their gardens, and their funerary monuments. The Musaeum — especially the elegant room decorated with twelve Emperor's heads in stucco over the windows-moreover provided a perfect setting for informal consultations among Strada's various patrons or the officials representing them, the scholars requested to contribute to the iconographical programme of festivities or ornamental schemes, and the artists involved in their execution. The decoration of the house, with the antiquities, art treasures and the library it contained, provided both a source of inspiration and concrete examples to imitate or emulate.

Strada's Musaeum also functioned as an office and workshop, in which he employed many assistants, to begin with the professional scribes who copied the text pages of the various manuscripts he had prepared. Then there were the young draughtsmen he had chartered in Rome to collaborate in the drawings for his Magnum ac Novum Opus, such as Giovanni Battista Armenini; a few engravers, such as Martino Rota, who worked for him in Vienna or elsewhere. His own son Ottavio likewise contributed to the libri didisegni, prepared examples for the engraver, and, until his break-up with his father, helped organize and supervise the proceedings. Strada also employed one or two sculptors to restore the antiquities he had acquired for Duke Albrecht and for the Emperor, and perhaps for other projects. These latter tasks required a separate workshop on the ground floor, apparently situated in an annexe to his house. It is perfectly possible that some of the preparatory work for ephemeral decorations was also done here, under Strada's own direct supervision: one could think of the pattern sheets for costumes, the three-dimensional scale models for triumphal arches, and the clay bozzetti for plaster figures. The terracotta sculptures used in the decoration of the Imperial Chamber in Bučovice give some impression what these latter may have looked like.

\subsubsection{The Musaeum as an Economic Entity}

The stress Strada placed on his Musaeum makes clear that he considered it as an important element of his professional as well as his social identity, and that it was central to his efforts, or rather to his enterprise. That was not only because it was the place of manufacture of the libri di disegni, his bestdocumented source of income, but also because it provided the bases of much wider-ranging commercial operations. There are many indications that Strada operated within the field of international commerce: his international network of relations; the occasional glimpses we have of him providing financial or other economic information; his acting as a go-between in financial matters between the French ambassador and the Nieri, the bankers from Lucca resident in Nuremberg who elsewhere turn out to be his own business partners; 
his being approached for (and refusing) a substantial loan to the Papal Nuncio; his confident dealing when acquiring the huge collection of sculpture for the Duke of Bavaria in Rome and Venice in the late 156os; finally his disposing of his own 'Gewölb', or storeroom cum shop at the Frankfurt book fair-all this neatly fits into this supposition.

Yet if Strada was a merchant, he may not have been a very common type. It is clear that presenting himself as a scholar, a nobleman and a courtier, in his self-representation he would not have stressed the commercial side of his activities. In any case it seems that Strada's was a rather specialized trade, specialized both as to the commodities involved, and as to the markets targeted.

\subsubsection{Luxury Goods: Antiquities and Works of Art and Craftsmanship}

As discussed in chapter 12, the actual goods Strada seems to have dealt in were primarily luxury goods, and then mostly restricted to his own fields of expertise: works of art and fine craftsmanship on the one hand, and classical antiquities, probably chiefly coins and medals and sculpture, on the other. He moreover could provide his customers with related materials such as semiprecious stones or the custom-made containers for the wares he had sold them. How much of what he purveyed them was produced in his own workshop, how much he may have sold in commission for artists, master-craftsmen or dealers elsewhere remains an open question. A concrete indication exists only in the case of his old Nuremberg neighbour Wenzel Jamnitzer: their earlier collaboration suggests that Strada may have continued to function as his agent at court. Maximilian II's extensive patronage of Jamnitzer-often in works that required very precise iconographical deliberations, such as the reliquary for the Empress Maria and the famous bronze and silver-gilt fountain - certainly does not contradict this supposition. It might well be that Strada's house also offered more modest, more standardized objects from Jamnitzer's workshop, such as silver drinking cups and plates which graced the aristocratic sideboard and would have been eagerly acquired by competing courtiers. The books of drawings of goldsmith designs produced in Strada's studio could also have functioned as trade catalogues from which patrons could select the type of objects they wished to order. That Strada did not limit his acquisitions for his patrons to antiquities only, is suggested by a passage in a letter Fugger wrote to him in November 1568, instructing him about the 'camei et gioie' Strada was to send to Duke Albrecht, which implies ample confidence in his judgement and probity. ${ }^{22}$

22 Doc. 1568-11-13: in a lost letter of 6 November Strada had asked whether the princes (the Duke and his sons) wished to receive them immediately, or rather wait until he could 


\subsubsection{Intellectual Goods: 'Libri di disegni', Manuscripts, Books and Prints}

Even if some of the books of designs kept in Strada's studio were meant as visual catalogues of the goods he could purvey, similar books of drawings themselves were provided to his patrons. Strada mentions the production of such libri di disegni as one of the principal activities he engaged in for Maximilian II. Several of them are found in the inventories of the Kunstkammer in Munich and that of Rudolf II. The best known of such albums actually produced in Strada's workshop and sold to his patrons are the numismatic albums provided to Hans Jakob Fugger and Duke Albrecht v of Bavaria-now mostly in the Forschungsbibliothek in Gotha-and to the Emperors Ferdinand I and Maximilian II, preserved in Vienna. Other examples are the set of drawings of the frieze of the Column of Trajan he provided to Vilém z Rožmberka, the albums containing a comprehensive series of beautifully illuminated series of coats of arms of princes, cities and noble families of the various Italian states made for Hans Jakob Fugger, the manuscript of technical inventions now in a private collection, and the various volumes containing images of designs for goldsmith work in an antique style just mentioned. The inventories of the Kunstkammer of the Duke of Bavaria, the Archduke Ferdinand II of Tirol at Ambras, and later that of Rudolf II in Prague, all list such volumes, either by Jacopo or by his second son Ottavio, who continued this practice after his father's death on an even larger scale. ${ }^{23}$

Apart from such luxury objects produced in Strada's own workshop, he also purveyed manuscripts from other sources, both ancient and contemporary, such as the Greek texts found by his son Paolo in Constantinople, which Strada offered to Duke Guglielmo of Mantua, and which he could have provided with Latin supplements (either summaries or translations?). ${ }^{24}$ Strada's own activity as a publisher implies that, in addition to manuscripts, he also could offer a choice of printed books, at the very least those he obtained from other booksellers in exchange for his own books or-in the case of the Basle printer Pietro

present them in person: 'Circa li camei et gioie, el stara nella volontà delli pr[incip]i ad mandarli hora, o differirlo a tanto che voi possiate esser presente, il quale si rimette nella vostra commodità. 'Camei' might refer to antique as well as modern carved stones, but 'gioie' seems to refer to modern jewels.

23 On Ottavio's manuscripts, see Van den Boom 1988; Van den Boom 1996.

24 Doc. 1571-11-20, Strada to Guglielmo, Duke of Mantua, Vienna, 20 November 1571: '[Paolo Strada] me à anche mandato tutti gl'inventarii del[li] libri graeci che sonno in tutte quelle librarie graeche di Constantinopoli; delli quali creddo se ne averia bonissima conditione quando si volessero comprare, e quando fossero in queste bande saria un thesoro $<\ldots>\mathrm{A}$ presso a questi libri graeci io la potria far servire del suplimento de Latini, et con bonissimo mercato; a tale faria una sontuosissima libraria con non molta spesa.' 
Perna-in lieu of payment for outstanding debts. ${ }^{25}$ That Strada intended Maximilian II's library to profit from this occasion is another indication that his Musaeum functioned as a high-class bookshop and stationer, 'by appointment to His Majesty the Emperor', but also catering to the needs of his courtiers and the local intelligentsia. Given his own artistic and scholarly interests, Strada would also have traded in prints, maps and other items exclusive for their rarity, their erudition or their sumptuousness. Gian Vincenzo Pinelli's instruction to Nicasius Ellebodius to buy the new Vienna edition of Castelvetro's translation of Aristotle's Poetics in Strada's house ('aedes') shows that its reputation as a bookshop transcended the milieu of the Imperial court. ${ }^{26}$

\subsubsection{Strada's Clientèle}

With his exclusive bookshop Strada catered for two sections of Viennese society: the first consisted of the members of the aristocracy connected to the Imperial court and the diplomats visiting it, whose taste would have been for fashionable novelties, easy reading and illustrated materials, and perhaps some serious reading in practical fields such as law, history and warfare. The second consisted of the cosmopolitan intellectuals employed at court, including not only the humanists and lawyers acting as secretaries, auditors, diplomats or translators, and the clerics servicing the Imperial Chapel, but also several professionals expressly employed for their specialism, such as the botanists Dodonaeus and Clusius. This group wished to keep abreast of intellectual developments and required serious scholarly and scientific publications. They moreover rubbed shoulders with local intellectuals, in particular the professors of the university, the chapter of the cathedral, the Jesuit College, and the upper strata of the Vienna bourgeoisie. ${ }^{27}$ It is some indication of the intellectual stature of Maximilian's court that these sections overlapped to a considerable degree: Reichard Strein von Schwarzenau and Christoph von Teuffenbach are just two of many high-ranking nobles who were intellectuals in their own right.

Members of each group would moreover be interested to inspect the antiquities, the works of art and other objects of luxury that Strada's Musaeum offered. This would incite them to acquire or commission similar objects for themselves, perhaps directly from Strada, perhaps through his mediation from

\footnotetext{
25 Doc. 1564-oo-oo; Strada to Maximilian II, without place and date, cf. above, Ch. 11.4.

26 Doc. 1571-09-27, Nicasius Elebodius to Hugo Blotius; cf. above, Ch. 11.4.

27 Several of the court intellectuals, such as Lazius, held professorships at the university; several Vienna patricians, such as Wolfgang Lazius and his father-in-law, the Bürgermeister Hermes Schallautzer also held appointments at court.
} 
other artists or dealers of his acquaintance. They would moreover consult his materials and his opinions when preparing their own projects, such as the houses they planned to build in town or on their estates, the decoration of some particularly representative rooms, the commissioning of a family portrait or tomb, and so on. Such consultation increased Strada's goodwill at court, and by exchange may have brought him other, material advantages - think for instance of hospitality extended by his patrons to himself and his companions on his travels to Munich and Prague. ${ }^{28}$ Direct financial advantage he gained only when he sold objects from his collection or stock-in-trade, or when he provided concrete services, such as preparing a set of designs and/or eventually organizing and supervising an architectural or decorative project. In Chapter 12 it has been argued that such may have been the case for the design of the house of his Vienna neighbour, Christoph von Teuffenbach, and of the decoration of the suite of state rooms at Bučovice in Moravia.

\subsection{Strada's Influence: An Agent of Change}

\subsubsection{The Diffusion of Innovations}

In this way Strada's Museum, both as an emporium of books, antiquities and works of art, and as a more general clearing-house of information about upto-date ideas and artistic forms, therefore also as a source of inspiration, supplied the needs of a fashionable, cosmopolitan and intellectual elite. This elite consisted at least in part of an avant-garde of 'early adopters', in the anachronistic terms of modern communication: those who pick up new ideas, develop new tastes, try out new products, embrace new styles in the arts as well as in their way of life. Because of their curiosity, their intellectual flexibility, and their position, members of this group set the trends and exerted a certain influence on the ideas and tastes of their peers in the region. The very existence of such an avant-garde might give rise to a conscious reaction among patrons of a more conservative stamp, expressly opting for a more familiar, conventional style, conforming to national prejudice ('Teutsch', German, as opposed to 'Welsch', Italian). The Laubenhof of the Schallaburg in Austria, with its rightly famous terracotta decoration, may be an example of this: it seems to reflect such a conscious rejection of the new, Vitruvian principles as promoted by Strada and exemplified in some of the houses built for members of the cosmopolitan court-elite such as Schwarzenau, Bučovice and Kratochvile.

28 Thus on a trip from Vienna to Prague he could spend the night at Schwarzenau, belonging to Reichart Strein, and at Třeboň or Český Krumlov, seats of Vilém z Rožmberka. 
Similar groups can be found elsewhere in Europe: the French patrons of Sebastiano Serlio provide another example. The characteristics of such groups conform rather neatly with those of the group of 'innovators' and 'early adopters' postulated in the paradigm of the diffusion of innovations, as formulated in Everett Rogers' classic study first published in $1962 .{ }^{29}$ Based on extensive empirical research in widely diverging disciplines and in widely diverging cultural contexts, this paradigm provides a robust model for the transmission of new ideas, practices and technologies introduced into a social system. At least to some extent, this model can be-though rarely has been-applied to the diffusion of new intellectual and artistic phenomena in a given environment. It is worthwhile to apply some of its postulates and generalizations to Strada's and his patrons' roles in this process. ${ }^{30}$

\subsubsection{The Antique as Innovation}

In order to use Roger's paradigm to better understand Strada's place in the diffusion of innovations in sixteenth-century culture, it is first necessary to define those particular innovations that Strada may have helped introduce or disseminate in Central Europe. For the purpose of my argument, I have defined a complex of four closely related developments:

- the most important innovation is the interest in the material remains of Antiquity, and the use of the results of the study of these in contemporary art and architecture;

- closely related to this is Strada's espousal of the style of the Roman High Renaissance in architecture and decoration, which itself is strongly influenced by this study of the antique example;

- the stress on preparing, collecting and diffusing visual documentation on these subjects is perhaps the most original aspect of Strada's career;

- the development of institutional and systematic collecting in Germany, as pioneered by Hans Jakob Fugger and his circle, was brought into practice in the complex of collections realized in Munich, and was codified in Samuel Quiccheberg's Inscriptiones vel tituli Theatri.

29 Rogers 1962; I have used the fifth, extended edition of 2003, which includes an ample history of the research paradigm. I have treated the same theme, with a slight shift of emphasis, in Jansen 2015 .

30 Rogers 2003 reviews thousands of studies in 'the nine major diffusion research traditions', a quantitative breakdown of which is given in table 2.1, pp. 44-45; history, the arts and culture in the narrower sense are conspicuously absent. An abstract of the following argument was presented at the Colloquium Prag-Residenz des Habsburgers Ferdinand I, 1526-1564 (Prague, March 2015): Jansen 2015, pp. 205-207. 


\subsubsection{Connecting Concepts: The 'imperial theme' and the Encyclopaedic Mentality}

These themes are closely connected: they can be considered as a coherent complex or, as Rogers calls it, a 'cluster' of related ideas or 'innovations'. The first two both relate to the fascination Strada felt for the history and more in general for the accomplishments of the Roman Empire, as evident in his numismatic researches and his Epitome thesauri antiquitatum. This included an adherence to the version of the idea of the Translatio imperii that held that the Holy Roman Empire and its current ruler were the natural successors of the Roman Empire and its Emperors. As a vassal of the Gonzaga Duke of Mantua-a Prince of the Holy Roman Empire who was closely tied to its ruling dynasty - this would have come natural to Strada, and it would have been stimulated by his contacts with Hans Jakob Fugger, whose fascination with the Roman as well as the Holy Roman Empire did not preclude a very lively interest and active role in the politics of the Empire of his own day. Needless to say, this idea was shared by the Emperor and his court. The Imperial theme can be considered the Leitmotiv of Strada's career, as it is the basso continuo of much of the intellectual and political endeavour in the Empire. ${ }^{31}$

All these themes are interconnected by Strada's efforts to document and to collect and organise information-especially the information from Antiquity, which was accorded authoritative status. Such encyclopaedic ambition is typical of the sixteenth and early seventeenth centuries, and was expressed in the editions of Opera Omnia of classical authors, the publication of voluminous, often polyglot dictionaries, universal atlases and natural histories, the compiling of bibliographies, and the creation of collections or Kunstkammern with an erudite and scientific purpose. The activities of Hans Jakob Fugger, both before and after he moved to Duke Albrecht V's court at Munich, and of Fugger's circle, provide an important example of this encyclopaedic mentality, to many elements of which Strada, an early and active member of this circle, amply contributed. ${ }^{32}$

\subsubsection{Innovators, External Agents and Early Adopters: Key Roles in the Diffusion of Innovation}

Note that Strada was by no means the first, let alone the only innovator or agent of change in any of the several developments listed above. Their introduction

31 Cf. above, Ch. 9.8.

32 Somewhat later Francis Bacon would include such activities among the opera basilica, 'acts of merit truly fit for a king', he considered conducive to the advancement of learning (Bacon/ Johnston 1974, pp. 70-67); cf. Jansen 1993, pp. 74-75. 


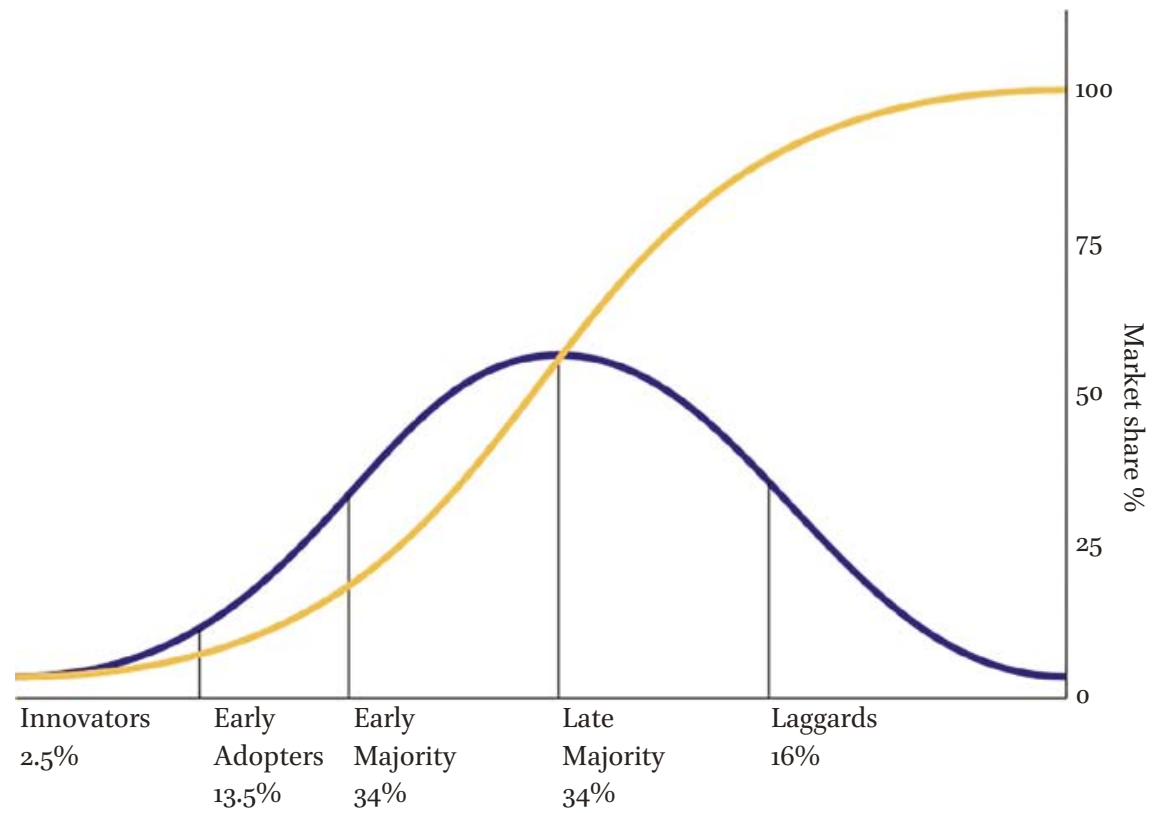

FIGURE 16.3 Graph showing the general rate of adoption of an innovation among various groups of the receiving social system; based on Rogers' Diffusion of Innovations, 2003.

should be seen as a long-term, complicated process of influences transmitted through many different means and channels of communication. But Strada did play an important role in this process. Application of the diffusion of innovation paradigm may help better to understand the nature of his particular contribution. This paradigm describes how an innovation-a new idea, technology or practice, which is either invented locally, or first introduced into a given social system by an 'external agent' - tends first to be taken up by a very limited group of 'innovators'. They are followed by a slightly larger and increasing group of 'early adopters', who, as 'opinion leaders', often are instrumental in persuading the later adopter categories - the 'early majority', the 'late majority' and the 'laggards' - to embrace the innovation. The rate of adoption of an innovation tends to follow an S-curve between its first adoption by the innovators and its general acceptance even by the 'laggards' [Fig. 16.3]. ${ }^{33}$

Characteristics of the 'innovator' are that he is 'venturesome', that he is interested in new ideas, less prone to prejudices, more disposed to take risks

33 The following paragraph is mostly based on Chapter viI, Innovativeness and Adopter Categories in Rogers 2003, in particular pp. 282-285, 'Adopter Categories as Ideal Types', and 287-292, 'Characteristics of Adopter Categories'. 
or better able to support possible failure (i.e. that he is richer), and that he has many contacts with the like-minded even when geographically distant (he is 'cosmopolite'). Characteristic of 'early adopters' is that they are better educated, more intelligent, are less prejudiced and less averse to change than later adopters, have a higher socio-economic status and are more ambitious. They are more curious about innovations, know more about them and have more contact with 'change agents'. Moreover they have wider social contacts both within and outside their own social system (they are more 'cosmopolite'). Because of their wide contacts and their higher status they enjoy the respect and the trust of their less advanced peers, and function as 'opinion leaders'.

\subsubsection{Strada's Associates as Innovators or Early Adopters}

Several of Strada's patrons can be described as innovators or early adopters. Hans Jakob Fugger is the most obvious innovator among them all: inspired by his study in France and Italy, supported by the worldwide network of his family firm ('cosmopolite'), extremely intelligent and infinitely curious, already at a young age he was the spider in an international web of scholars and printers. He played a very big role in the development of institutional, systematic collecting and documenting of information, both in his own right and later as the driving force behind the creation of the complex of collections in Munich, and as inspirer of the first theoretical treatise on the subject, Samuel Quiccheberg's Inscriptiones. As one of his agents Strada contributed objects to Fugger's library and collections and to those of Duke Albrecht, but he also contributed ideas: the stress on visual documentation in Fugger's collection and later in the Munich Kunstkammer and in Quiccheberg's treatise was largely due to his influence. The Fugger circle also played a role in the introduction of the High Renaissance style into Germany, witness the Fuggerhaus at Donauwörth, built in the 1540 s, in particular its pure, Vitruvian decorative elements such as portals, chimneypieces and the Stübchen discussed in chapter 3.4 [Figs. 3.38-3.45]. Considering Strada's close connection with the Fuggers just at that time, he must have been the source of the Mantuan elements in their style, and an attribution to him of their design is perfectly plausible.

Because of his wealth, his very wide contacts-including the Austrian Habsburgs and the Duke of Bavaria — and his political prominence first in Augsburg and later in Munich, Fugger was a natural 'opinion leader', witness the large number of books dedicated to him and the adoption of his ideas by the Duke of Bavaria. A similar natural role as an opinion leader was filled by Strada's princely patrons, the Emperors Ferdinand I and Maximilian II, 
Archduke Ferdinand II of Tirol and Duke Albrecht v of Bavaria himself. ${ }^{34}$ Several of Strada's aristocratic patrons-Vilém z Rožmberka, Jan Šembera z Boskovic, Reichard Strein von Schwarzenau and Christoph von Teuffenbach-fit the pattern of early adopters: of high social standing, highly educated, intellectual and cosmopolitan, they all adopted one or more of the innovations championed by Strada.

A similar role as an innovator or early adopter of new forms can be assigned to Wenzel Jamnitzer: compared to his colleague goldsmiths in Nuremberg, he is relatively well-to-do, is at ease corresponding even with high-ranking patrons outside his home-town, is venturesome, is curious and has intellectual interests, witness his treatise on perspective. As a neighbour of Strada, he was moreover bound to have relatively more contact with at least this one 'change agent'. From this point of view it comes as no surprise that Jamnitzer is one of the first goldsmiths in Nuremberg to adopt Italianate, classicist ornament, which may be credited at least in part to Strada's influence.

\subsubsection{Strada as a Change Agent}

If considered in his German habitus, Strada himself obviously can be considered as an innovator or early adopter, since he too practiced all the innovations mentioned in his own work and his other activities. But if he is considered first and foremost as an Italian this is less obvious, for in that case these innovations were not quite so new, or not new at all. Therefore his position in the paradigm is closer to that of the external change agent than to that of the innovator. A change agent is 'an individual who influences clients' innovation decisions' by introducing awareness of, and knowledge about a given innovation, and thus developing a need for, and creating an intent to change in the client, and helping him to translate that intent into action. 'One main role of the change agent is to facilitate the flow of innovations from a change agency to an audience of clients. $<\ldots>$ Change agents usually possess a high degree of expertise regarding the innovations that are being diffused $<\ldots>$ As a bridge between two differing systems, the change agent is a marginal figure with one foot in each of two worlds. ${ }^{35}$

This description seems to fit Strada like a glove. Likewise Rogers' generalizations describing the change agent's contacts with clients can be applied to

34 Ferdinand I can be considered an innovator, or at least an early adopter, because of his quite early interest in architecture and decoration in the antique manner, as described abov, Ch. 5.2.1 and cf. Holzschuh-Hofer 2010.

35 This is a very summary paraphrase of the change agent's roles as defined by Rogers 2003, Ch. 9 , in particular pp. 366 and $368-369$. 
Strada's contact strategy: he tended to target patrons whose characteristics conform to those postulated in Rogers' definition of 'opinion leaders', that is patrons who possessed 'a higher socio-economic status, $<\ldots>$ greater social participation, $<\ldots>$ higher formal education $<\ldots . .>$ ' and a considerable degree of 'cosmopoliteness.' ${ }^{36}$

\subsubsection{Was there a Change Agency?}

According to Rogers' definition already partially cited above, a change agent 'influences clients' innovation-decisions in a direction deemed desirable by a change agency' [italics mine], that is an 'agency' employing the agent deliberately to introduce a given desirable innovation. ${ }^{37}$ One should not discount the possibility that even in the Early Modern period a government might have developed a conscious policy - albeit in a rudimentary form - to collect information about useful novelties from elsewhere, and to find means to disseminate this among its dependents, in order to increase its prestige, its prosperity and its power. Elsewhere I have argued that the Munich complex of collections, as realized by Duke Albrecht v of Bavaria and Hans Jakob Fugger, and theoretically justified in Quiccheberg's treatise, was in fact primarily considered as a source of information, of knowledge, and was motivated as much by a conviction of its public utility as by more conventionally accepted incentives, such as the private intellectual and aesthetic pleasure of the prince, the need for formal representatio and dynastic propaganda, or the need to express the philosophical correspondence between macrocosm and microcosm. ${ }^{38}$

This is not the place to argue the existence of a more or less rudimentary cultural policy in Munich or Vienna-but assuming that such a conscious intent to foster progress in the arts, sciences and scholarship existed, Strada's employment first by Fugger, and then by Ferdinand I and Albrecht V, suddenly seems very consistent. Fugger certainly was interested to foster scholarship, as is borne out by his massive moral and financial support of a whole crowd of scholars and scientists and the creation of his huge library; as we have seen he fits the profile of the innovator to a large extent. With a small but choice collection of antiquities, Fugger also inherited an interest in that field from his father. Especially numismatics and its application in scholarship was a relatively new discipline, with some of its roots in Augsburg and Nuremberg itself, but being developed at the time in Italy in the learned circles in which Fugger had moved during his all too brief period of study. For that reason he turned to Strada,

$36 \quad$ Rogers 2003, p. 382 and 388.

37 Rogers 2003, p. 366.

38 Jansen 1993(b), especially pp. 64-68; slightly revised reprints Jansen 2005 and Jansen 2013. 
whose own interest in the field and qualities as a draughtsman must have been known to him either through earlier acquaintance in Italy or through Strada's activities in Germany. Strada's competences and curriculum perfectly fitted Fugger's purpose. He may well have arrived in Germany in the course of the most spectacular introduction of an Italian novelty in Germany, the construction of the Italienische Bau of the Stadtresidenz in Landshut. Already while active in Germany in the 1540 s he collaborated with the most advanced or innovating of the local artists, Wenzel Jamnitzer. Fugger's commissions enabled Strada to develop his own numismatic method: though not revolutionary, this was itself innovative in a quiet sort of way, as shown in the preceding chapter, and its results were published in a format which was quite advanced even for Italy. Thus, in supporting Strada's studies, Fugger acted as an innovator. But he also acted as an early adopter when he accepted some ideas-such as the importance of visual documents as sources of information, and the method to pursue these, from Strada in his role as a change agent. When Fugger moved to Munich it was natural that he would continue to employ Strada, by that time an associate of well over a decade, to assist him in giving shape to Duke Albrecht's cultural and intellectual ambitions.

Moreover it was probably Fugger who, as a trusted opinion leader, instigated or at least facilitated Strada's introduction to another patron, Emperor Ferdinand I. Just like Fugger, at an early date Ferdinand had shown himself interested in at least two of the innovations Strada promoted: classical numismatics-Ferdinand had just commissioned a description of his own coin collection - and the use of the classical style in architecture, as shown in his building activities both in Prague and in Vienna. As discussed in Chapter 5.2, both Ferdinand I and his two eldest sons, King Maximilian of Bohemia and Archduke Ferdinand II of Tirol, had been aware of the new ideas even before Strada arrived at court, mostly through their dynastic and political ties both in Italy — such as Mantua - and in other countries in Europe, in particular the courts of Emperor Charles V and King Francis I of France. Peer pressure, the need to uphold their status in relation to such royal relatives, to the wealthy Princes of the Empire-such as the Elector of Saxony and the Dukes of Bavaria and Jülich —and to the richest magnates in their own territories—such as Rožmberk and Strein von Schwarzenau—stimulated their personal interest and their ambition to introduce suitable innovations in their own domains. As in Munich some consciousness that this fostered progress, that it served the political, military and economic interests of the dynasty, and contributed to the prosperity of their peoples, must have played a role. The appointment at court of learned men who appear to have been employed primarily to do their own work - some of them quite famous in their respective fields, such as 
Lazius, Sambucus and Clusius - fit neatly into this view, as does the appointment, a little later, of the first Imperial Librarian, Hugo Blotius. ${ }^{39}$

This supports the contention that Strada likewise was deliberately employed to introduce or at least to promote some of the desired innovations in antiquarian scholarship and the arts. Strada's offer to move to Vienna with his family, his workshop and his collection, and his later investment in building a splendid mansion in an extremely advanced style to house these, must have been very welcome to his patrons. It created a minor but exquisite and advanced centre of arts and scholarship, which contributed to the attraction and prestige of the Vienna court, at relatively little cost to the Emperor. In exchange for their facilitating Strada in setting up shop in Vienna, his august patrons probably implicitly expected him to open his Musaeum to, and share his expertise with their courtiers and with the artists, scholars, and other functionaries they employed. Thus Strada's role was to diffuse the innovations he brought with him in their lands. The Emperor himself led the way in this by commissioning Strada to purvey suitable material for his collections and designs for some of his projects, and in using him as a consultant for other ventures. In this sense the Emperor can be considered the 'agency of change' that deliberately employed Strada to function as a 'change agent'.

\subsection{8 'Et io curioso di giovar al mondo': Strada's Promotion of Antiquity and Italian Art}

That a cultural policy, actively, consciously and conscientiously promoting the introduction and diffusion of new ideas and artistic forms in their dominions, was pursued by Ferdinand I and Maximilian II, and that they employed Strada to that purpose, remains a hypothesis. Strada's activities, however, do demonstrate abundantly that he himself did deliberately and expressly promote the study of Antiquity, the dissemination of knowledge both in text and image, the use of the formal language of the Italian High Renaissance-especially its Roman variant - in the arts and in the architecture of his adopted country, and finally the use of the image as a means of serving all of these ends. In part this promotion should be seen as the promotion any craftsman, artist, merchant or scholar would engage in to sell his wares or to obtain commissions or a job. But both the scope and the tone of Strada's efforts transcend such elementary

39 The iconography of Maximilian's famous silver gilt fountain, whose significance must have been closely directed by himself, centres on both the monarch's rights and his duties towards his people (cf. above, Ch. 2.5.4). Blotius' unsuccessful attempt to turn Maximilian's court library into a truly Imperial library, i.e. a sort of central library for the Holy Roman Empire, reflects a similar consciousness of its public function and utility; cf. Brummel 1972, pp. 6-80; Siegert 2004. 
marketing, and show that he really thought the new ideas, forms and images he proposed and worked with could, and should benefit his contemporaries, and enrich their mental and artistic world.

Such an ambition to be useful to the world was often expressed in texts published at the time, and Strada was no exception: it was repeatedly referred to both in the prefaces to the books he published and in his correspondence. Thus in the preface to his Epitome thesauri antiquitatum he castigated those contemporary numismatist who 'obstinately keep their labours hidden in their studies, without wishing to share them with anyone', and presented them his book in order 'to show the way to imitate it, or to surpass it, with the help of God, their talent ("nature"), and their learning ("doctrine"). 40 The very first line of Strada's dedication to Duke Albrecht $v$ of his edition of Caesar's Commentaries referred to its public utility. He then added a two-page paean of the Duke's library and collections, not forgetting Fugger's contribution, and ended comparing the Duke with Caesar as Pater Patriae, implying the utility to his people of the Duke's new institutions. ${ }^{41}$ In his introduction to Serlio's Settimo Libro he likewise stressed its use to the public in general, and to the practitioners of building in particular:

Now examining this book, I judged it to be the most beautiful work, and the most useful that he [Serlio] ever made, and I wished to benefit the world with it, because of the facility he maintains in his writing, and teaching the world how to build. For even though there are many and different methods [to build], he nevertheless teaches these (whatever their difficulty) with such skill, facility, and good order, that any man, however mediocre in his art, is made competent [in it] and can easily serve himself of these [methods].

He motivated his adding a Latin translation by a similar wish, not only to make the work accessible, but also to have its precepts applied in 'all the kingdoms and provinces of the world' 42 The copyright privileges of Strada's works and

$40 \quad$ Strada 1553(b), fol. Aa 4r.: 'Car par ce qu'ilz detiennent obstinément tels labeurs cachez en leur maisons sans en vouloir faire part à personne, ie leur presente cest Epitome, pour montrer le chemin, pour le suivre, ou surpasser aydant Dieu, nature et doctrine'.

'Qui in lucem ad utilitatem publicam opus aliquod suum sunt edituri ...'; Caesar 1575, fol. ${ }^{*} 2$ r.; fols. *3v. -5 r.; partial German translation in Hartig 1917, pp. $286 \mathrm{ff}$.

42 Serlio 1575, fol. a iii-v.: 'Hor' esaminando bene questo libro giudicai che fosse la più bella fatica, e la più utile, ch'egli havesse già mai fatta, et io curioso di giovar al mondo con essa, per la facilità ch'egli tiene nel suo scrivere, et insegnare il mondo di fabricare, le quali se ben sono intante e varie forme (quantunque sono difficili) egli non dimeno le insegna con 
his requests for subventions for these likewise stress their public utility: thus in 1573 he requested a privilege from Maximilian II for his seven books of inscriptions, which he wished to print 'to the common utility of everyone'. In 1577, after Maximilian II' death had 'spoilt all his efforts', he begged Francesco I to revive his labours, hoping the Grand Duke were willing to 'provide this benefit to the world. 43

Of course these phrases were commonplaces, but they were not for that reason less sincere: Strada appears to have practiced as he preached. The best indication for that is the huge collection of visual documentation he built up in those fields that most interested him. Partly this collection consisted of the material he gathered on his travels, or could acquire by fortunate chance. Yet his wholesale acquisitions of the complete graphic estates of Serlio, Perino del Vaga and Giulio Romano - which might seem just so many lucky opportunitiespresuppose his active approach of their possessors: why did he buy just these collections? In addition Strada developed a systematic programme of acquisition of very precise, high quality documentary drawings of selected monuments both of classical Antiquity and of its most illustrious modern reinventions, a project involving many draughtsmen and what must have been a quite substantial investment. Some of these sets-notably the documentation of Raphael's Vatican Loggia and of the Palazzo del Te-were commissioned on behalf of his patrons, but it seems rather likely that Strada had himself incited their desire for these, before satisfying it.

tanta destrezza, facilità, e bell'ordine, che per huomo mediocre nell'arte che egli si sia, lo fà capace, e sene può commodamente servire'; 'Hora vedendo la utilità che questo libro al mondo haverebbe potuto arrecare, se fosse inteso da ogniuno, lo feci tradurre in lingua Latina, come quella che è più intesa di tutte le altre ch'hoggi dì si scrivono, e parlano fra Christiani: accioche fosse da tutti li regni e provincie del mondo inteso, e posto in opera'.

Doc. 1573-00-0o, Request for copyright privilege for a seven volume compilation of ancient inscriptions: 'Mi trovo sette gran volumi scritti di lettere maiuscule, parte latine e parte greche, dove sonno tutte le inscriptioni antiche, che in varie parte del mondo si trovano; e perchè sonno molti anni che io le ò messo insieme, imperò con hanimo di publicarle sotto il nome della Sacra Cesarea Maestà Vostra alla stampa a commune utilità di ciascheduno.; Doc. 1577-10-04(d), Strada to Francesco I, Grandduke of Tuscany: 'Ma la morte à guasto hogni cosa, si che se Vostra Serenissima Altezza volesse far questo benefitio al mondo, et lassar immortal nome et gloria di Lei con il fargli stampare, tutto sta in quella.; Doc. 1581-01-04, Strada to August, Elector of Saxony, request for subvention for his polyglot dictionary: 'Il Pr[esen]te, che V. Alt. Mi fece dei talleri 500 par aiuto del mio Dictionario, che V.Alt. vide, tutti furono spesi con molti altri apresso in far scrivere; hora tutta la mia fattico che io ho fatto, con tanta mia spesa, tutto dorme, et dormira per insino che qualche Principe non si degnara di far le svegliare per publica utilità al Mondo'; there are many other instances. 
Whatever the quality of the material Strada brought together or purveyed to his patrons, most of it was collected not for its intrinsic artistic value, but for its potential use as a model. In contrast to Vasari, Strada appreciated even his most wonderful drawings not so much for their status as exemplary autograph works of outstanding individual artists, but rather because they provided a storehouse of models of the treatment of given iconographical themes, of motifs and 'inventions', and more in general as a source of inspiration for new works. That is the reason why he valued even relatively low-quality copies, if nothing better was available. He did not hesitate to offer these also to his patrons: if Archduke Ferdinand II of Tirol's copy of the frieze of Column of Trajan was purveyed by Strada - which seems the most likely option-it shows that at least in this case both patron and salesman were more interested in the information the album presented — both as an historical source and for its visual motifs - than in its aesthetic qualities [above, Figs. 13.89-13.90]. As we have seen, it seems to have made little difference to Strada whether the model was genuinely antique — say the Column of Trajan — or an authoritative modern example of the antique manner - say Giulio's comparable double frieze in the Camera degli Stucchi of the Palazzo del Te: both provided information on the warfare of the Romans, and both could be used as sources for new works of art. Strada's efforts in collecting such material can thus be linked to the current practice of artists of his time to lay in a private stock of sketches and (copies of) drawings and prints, to be used as a source of inspiration and of motifs to draw upon for their future works. But its extent, and the systematic way he set about it, show that he more or less institutionalized this practice, and that the collection he brought together was intended to inspire patrons as much as the artists they employed.

Strada's house in Vienna was built especially to house and to display this Musaeum - his huge library, his collection of graphic documentation, his coin cabinet and other antiquities, his paintings and other works of art. The house itself was designed as an explicit example of the new, correctly Vitruvian architecture as developed in the Rome of the High Renaissance. It was conceived as a model, a demonstration of the application of the 'innovations' Strada wished to propagate. His pride in it, the way he offered its use to his patrons, and shared its amenities with his colleagues at the Imperial court and its foreign guests, show that he made it readily accessible at least to a high-placed, well-to-do, well-educated and cosmopolitan court-elite. These were the 'early adopters' Strada targeted, to whom both his house and its contents provided information, inspiration and concrete models for their own initiatives.

The best and most explicit argument for Strada's enthusiasm to propagate his ideals is his publishing programme, as exemplified in the various copyright 
privileges and in the Index sive catalogus. The Index, in which all the 'innovations' listed above are represented, reflects the breadth of Strada's ambition. Its intensity is indicated by the unrealistic megalomania of his project, by his perseverance in it against all odds, and by the huge portion of his patrimony he appears to have invested in it. The best indication for the sincerity of his ambition, even his passion, is the increasingly despairing tone in his begging letters to potential sponsors of his projects. This despair is echoed in the dispositions of his testament, which shows him willing to largely sacrifice his children's inheritance in order to realize his projects at least posthumously.

\subsubsection{The Effect of Strada's Promotion of Intellectual and Artistic Innovations}

Strada's desire to promote those intellectual and cultural phenomena he so highly prized himself, is sufficiently evident to ask the question in how far he was successful in this ambition. As Chapter 14 has made clear, his success as a publisher was marginal: most of his projects never came to fruition, and consequently his influence, if any, remained limited to a sphere allowing physical access to himself, his works and his collections. The only exceptions are his own Epitome thesauri antiquitatum, which was a bestseller and was soon reprinted in pirated editions, and Serlio's Settimo Libro, which was a very useful part of the treatise, and henceforth reprinted continuously together with its other published volumes.

But even if Strada's influence remained limited to those with physical access to his collection and to himself, his influence must have been considerable, in view of his central position at the Imperial court, his continuous travels covering a wide region, his very extensive network, and the status he derived from these. It is obvious that he directly influenced the projects in which he was himself involved as a designer, such as at the Munich Antiquarium and the Vienna Neugebäude, or as an advisor, such as the tomb of Emperor Maximilian I and the ceiling of the Goldene Saal in Innsbruck. Given that such advice was rarely documented, and that his material was accessible to his patrons and the artists they employed, it is not unreasonable to assume that other projects were likewise influenced by it. Good examples of such influence are the stucco ceilings in Archduke Ferdinand II's hunting lodge Hvězda in Prague, begun very soon after Strada's personal visit to the Archduke in Prague, and those in the castle at Nelahozeves, commissioned in the mid-156os by Emperor Ferdinand's counsellor, Florian Griespek von Griespach. Both reflect knowledge of Giulio Romano's decorations, and appear to use iconography derived from antique coin-reverses: information that for Habsburg courtiers at that date was most easily accessible in Strada's collection. 


\subsubsection{0 'Queste cose meglio si danno ad intender a bocca et con l'operare che con lettere'}

Given the accessibility of Strada's Musaeum, it can be concluded that its contents schooled the taste of his patrons, their courtiers, the artists they employed, and others having access to it. This included the members of the dynasty themselves, such as the young Rudolf II and his brother Ernest, who appear to have learned to draw in Strada's studio and after his models. The tone of the passage in Strada's letter to Dietrichstein which allows this conclusion, shows how much Strada was convinced of the value of draughtsmanship, and of drawing as a source of knowledge and an aid to understanding. He translated this conviction into practical didactic activity at least in the case of the two Archdukes and of his own sons Paolo and Ottavio - in the latter case with conspicuous success. ${ }^{44}$

Such didactic use, and more in general Strada's own explanations of the materials of his Musaeum and his demonstrations of the use to which they could be put, were as important for the effect of his efforts as the presence of these materials in itself. Much of the material would not have been easily comprehensible to those who saw it for the first time: even the vaunted 'simplicity' of Serlio's writings would become more accessible to local patrons and practitioners when the finer points were explained by Strada in person. When in December 1556, at Jamnitzer's suggestion, Strada offered his services to Archduke Ferdinand, he said as much, offering to come to Prague for a personal interview with the Archduke because 'those things are better explained by word of mouth and in demonstration than by correspondence. ${ }^{45}$ In a similar way Strada's comments on the history and iconography of the works of art he owned or had had documented, on the significance of the inscriptions and the images on the ancient coins he could show, on the rules of Vitruvius as applied in Serlio's manuscripts, and on the designs he provided himself for projects at court, enhanced the value of his materials, as did his account of his first-hand experience of their context, his personal acquaintance with the authors and artists of such works, and often even with their patrons. All these contributed to the acceptance of his materials as authoritative models for emulation, as did the high standing of the magnates and princes who had patronized his own activities - the Marquis of Marignano, Hans Jakob Fugger, Vilém z Rožmberka, the Duke of Bavaria and the Emperor himself. Such patronage invested his expertise with a matchless authority — matchless at least among the artists active at court.

44 Cf. Chs. 11.5 and 14.2.

45 Doc. 1556-12-22. 
In this study a number of examples have been suggested where Strada's influence and that of the materials in his Musaeum can be discerned-the classical and Italianate elements in Jamnitzer's work, the Stübchen in the Fuggerhaus at Donauwörth, the stucco at Hvězda and Nelahozeves, the Stallburg in Vienna and the Landhaus at Graz, the Munich Antiquarium, the tombs of Maximilian I in Innsbruck and Ferdinand I in Prague, the interior decoration of the Imperial residences at Vienna, Innsbruck and Pressburg, the Neugebäude and the Ernestinische Trakt in Vienna. This influence might be extended with a number of houses and castles in Austria and in Bohemia built for noblemen connected to the Imperial court. The influence of Serlio's treatise, which is so often noticed, can be much better explained by the presence of the bulk of Serlio's manuscripts and beautifully executed drawings in Strada's collection, than by reference to the circulation of the printed volumes of the treatise. In the case of the concept of the type of 'palazzo in fortezza', imitated in the castles of Bučovice, Drnholec, Schwarzenau, and the manorhouse at Kratochvile, this is even a necessity, since their obvious models are included in the Sesto Libro, which remained in manuscript until the facsimile editions of the late twentieth century. Likewise the decorations in the chapel of the castle at Pressburg, the painted ceiling at Strechau castle, and the stucco and painted ceilings at Bučovice can best be understood with reference to the splendidly illuminated documentation of Raphael's Vatican Loggia which was in Strada's possession. A fresh look at the architecture and decoration of the later sixteenth century in Austria and Bohemia from this point of view, doubtless could provide some more examples.

The development of Renaissance and Mannerist art and architecture in Central Europe cannot be fully understood without making allowance for the effect of the various agents transmitting the ideas, values and forms of the Italian Renaissance in the region. Among such agents Jacopo Strada played a leading role: because of his privileged position, because of his Musaeum, because of the example he set in his own practice; but most of all because he was deliberately and effectively promoting or diffusing the innovations that were the essentials of the new style.

\subsection{Conclusion: Strada's Personality}

'An elusive, universal personality of great versatility and flexibility, who often changed his residence, range of action and activity'. Thus Fritz Schulz characterizes Strada in his article on Strada in Thieme-Becker. ${ }^{46}$ It is true that

46 Schulz 1938: 'Schwer fassbare, universelle Persönlichkeit von grosser Vielseitigkeit und Wandelbarkeit, die Wohnsitz, Wirkungsstätte und Tätigkeit häufig wechselte'. 
at first sight Strada appears to fit the prototype of the polyhistor, the proverbial universal 'Renaissance Man'. Certainly he displayed the wide interests, the erudition and the cosmopolitan outlook that were the consequence of his considerable intellectual and artistic gifts, his courtly education in Mantua under the aegis of the Gonzaga dukes and Giulio Romano, and the opportunity he had to travel widely even in his youth. His project for a polyglot encyclopaedia of unprecedented size likewise presupposes a universal interest in all sciences. Yet the survey I have given shows that - however wide his interests may have been-he specialized primarily in the history and the material remains of the classical past, and in the visual arts and the architecture of his own day. In fact many important disciplines, such as theology, law, medicine, most of the natural sciences, and music are conspicuously absent in his professional activities, though they were probably amply represented in his library. And even his polyglot dictionary, based as it appears to have been on the written sources from Antiquity, probably would have resulted in a fictive reconstruction of the erudition of the Ancients, rather than a codification of contemporary science. Strada's merits as a scholarly antiquary are modest: as one of the earliest authors of a more or less systematically ordered, illustrated numismatic treatise, he has a small but not unimportant place in the history of classical scholarship. But the greater part of the results of his numismatic research remained in manuscript, was relatively inaccessible and has hardly been studied. Much of the other antiquarian material he collected has been lost or is not as yet identified.

\subsubsection{Strada's Artistic Personality}

Nevertheless the fact remains that Strada is an unusual example of a person combining a serious and sustained scholarly interest in the history and culture of the ancient world with a passionate love and great understanding of the visual arts. This was an unusual, though not unprecedented combination, which was found earlier in Raphael and his pupils - in particular Giulio Romano - and in Sebastiano Serlio: three shining examples who provided the inspiration for Strada's ambition, and helped him develop his procedures. This combination of interests was also found in other artist-antiquaries who were his more exact contemporaries-such as Pirro Ligorio, Enea Vico and Andrea Palladio - who were steeped in the antiquarian lore as practiced in Rome both before and after the Sack of ${ }_{1527}$, as much as Strada himself.

It should be said that - unlike Raphael, Giulio and Serlio or Palladio and Pirro Ligorio-Strada was no great artist. His own taste was what one could expect from a pupil of Giulio Romano and of Serlio: he preferred an elegant, 
'learned' style based on a very extensive knowledge of antique monumental architecture, figurative motifs and decorative schemes. It was an ornamental, 'stylish' Mannerism as defined by John Shearman - though perhaps in Strada's case the stylishness comes sometimes close to pedantry. ${ }^{47}$ His personal style is best exemplified in his splendid designs for his printer's marks, the ornamental title pages of his numismatic manuscripts and the festival designs which can be attributed to him. On occasion these include designs of which the stylish, architectural simplicity seems to prefigure the severe Neoclassicism of the early nineteenth century [Fig. 16.4].

In architectural design, the field in which he probably was most talented, his efforts were rooted in a sophisticated comprehension of the Vitruvian architecture of the Roman High Renaissance, in particular that of Raphael and Giulio. They resulted in elegant designs which can be richly ornamented-as in his design for the Munich Antiquarium and in many of the reconstructions of ancient monuments based on coin reverses in his numismatic albumsbut which are equally, or even more effective when devoid of ornament. This is evident in the designs for his own house and that for the Stallburg in Vienna, which is the next best candidate for an attribution to Strada, both as to its conception, its detailing and the timing of its planning. ${ }^{48} \mathrm{~A}$ typical characteristic of his architecture is the recurrent use of coupled columns or pilasters, a motif which is relatively rare in sixteenth-century architecture, but can be found in both the exterior and the interior articulation of Strada's Antiquarium designs, and in the façade of his own house. Its use in the interior and exterior elevations of the Vienna Neugebäude is the most forceful stylistic argument for his decisive participation in the design process of that extraordinary creation.

\subsubsection{Talent Spotting and Networking}

Though not a great creative artist, Strada appears to have had an exquisite taste, a sensitive eye and an intellectual comprehension of the artistic achievements of his time. He also seems to have had a nose to find out and employ associates and collaborators still recognized today as leading representatives of their respective disciplines in all the places where he was active. Examples include, in Nuremberg: Wenzel Jamnitzer and later Jost Amman; in Lyon: Serlio, Bernard Salomon and Guillaume du Choul; in Rome: Antonio Agustín, Onofrio

47 Shearman $1967 / 1977$, especially Ch. 1.

48 Cf. above, Chs. 7 and 6.5 . 


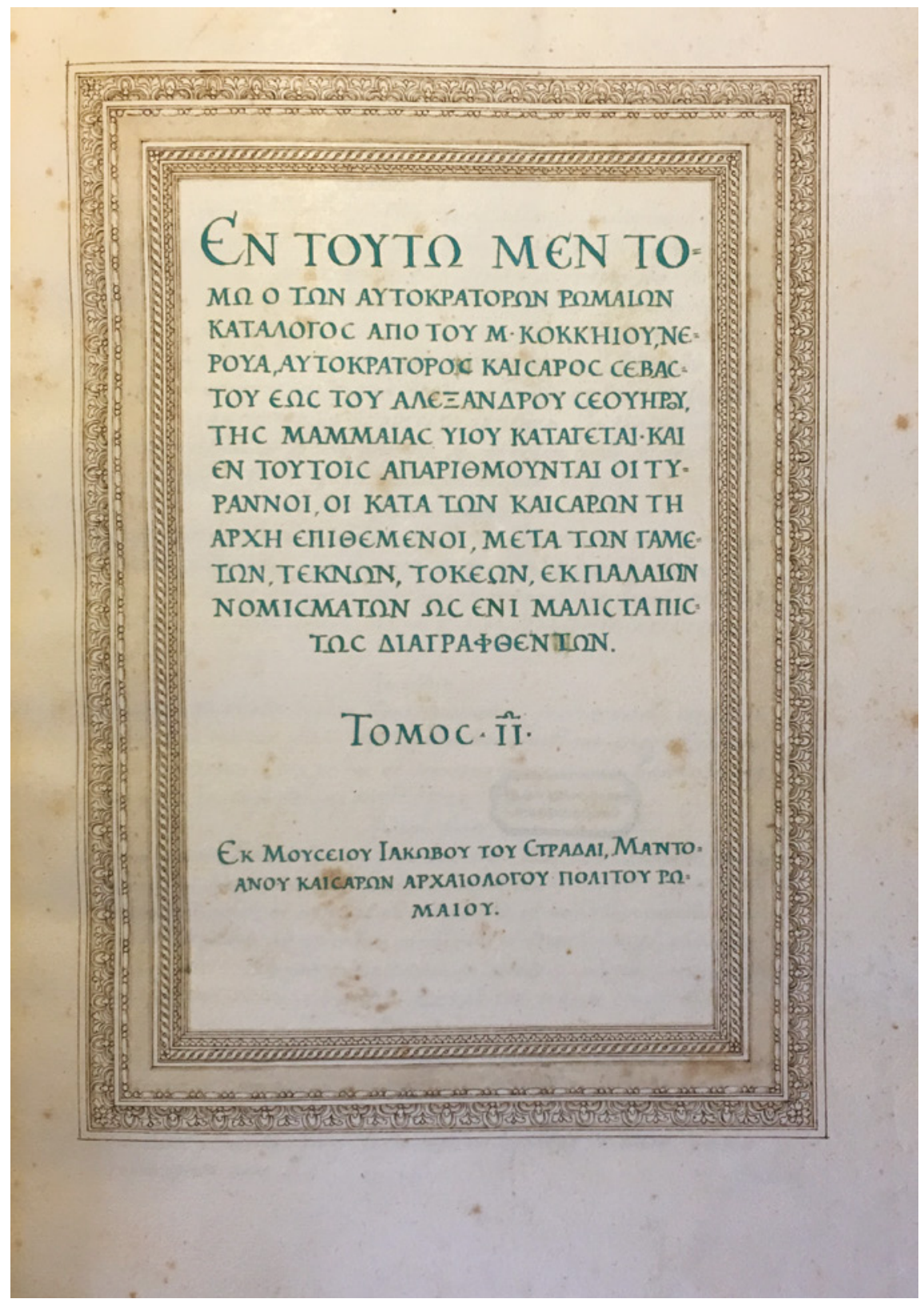

FIGURE 16.4 Workshop of Jacopo Strada, title page of the second volume of his Series of Greek coins commissioned by Emperor Maximilian II; Vienna, Österreichische Nationalbibliothek, Cod. 9417 . 
Panvinio, Pirro Ligorio and Enea Vico; in Mantua: Giovanni Battista Bertani, Giovanni Battista Scultori and Ippolito Andreasi; in Venice: Titian, Tintoretto and Alessandro Vittoria; in Vienna: Martino Rota; and in Frankfurt Andreas Wechel and Sigmund Feyerabend.

Strada's active talent spotting is mirrored by his extensive network of contacts, described in Chapter 11. His personal status as a nobleman, his recommendations from the Gonzaga Dukes, and at least some financial independence even in his early days, all were necessary conditions to build up this network. But his personal talents, his curiosity, his cosmopolitan attitude and his self-confidence must have played at least as large a role. It was this that obtained him the patronage of such an extraordinary man as Hans Jakob Fugger; it was this that helped him to wed his noble bride; it was this that allowed him not only to attend the 1548 Imperial Diet at Augsburg, but also to land an important commission from one of Charles v's principal supporters. It is clear that Strada sought such contacts actively, for the input they providedknowledge, ideas, materials and further contacts-as well as for the output they allowed, by providing patrons to pay for the projects he planned, and an audience to insure their reception.

Such active talent spotting and deliberate networking in the places Strada visited or where he settled, best show how consciously and conscientiously Strada attempted to disseminate the knowledge, the ideas and the artistic forms he admired. This is the principal reason why he is of significance for the cultural history of the sixteenth century: because he stimulated the awareness of the connection between classical erudition and the visual arts, and because he carried the paradigm of the pre-eminence of the classical example and of the Vitruvian precept in architecture for contemporary artistic creation across the Alps. Just as Serlio did in France, he propagated this paradigm in Central Europe, and stressed its suitability for local use. Like Serlio, he popularized the concept and the forms in which it was expressed among a select group of patrons, potential 'opinion leaders' and 'early adopters'. He did this by bodily carrying both classical and contemporary examples with him, thus transforming his patrons' collections and his own into centres of diffusion both of the antique example, and of the new style that was inspired by it. He did this by making available his huge collection of documentation of authoritative examples from Antiquity, and of equally canonical contemporary achievements that had been inspired by it; and he did this by the example of his own designs. Last but not least, he did this most of all by his comments and explanations on all of these.

There can be no doubt that some of Strada activities - in particular the 'traffic' in antiquities and works of art—were partly motivated by commercial 
considerations. Yet there can be no doubt either that they were motivated at least as much by Strada's sincere enthusiasm for his subject of study, and his conviction that it could be of use to his patrons, and to society in general. A conviction which caused him to invest far more in his projects than was commercially justified, and —in the last decade of his life - to be prepared to sink most of his and his family's patrimony into their realization.

\subsection{Epilogue: Back to the Portrait}

It is this enthusiasm that is shown in Titian's portrait [Figs. 16.5-16.6]. For my part, biased as I am by my study of Strada's career, I do not see it as the 'particularly unattractive sort of eagerness' that Pope-Hennessy detected in Titian's masterpiece. In fact, his case for the prosecution is sufficiently damning that it demands a plea for the defence, which I will present point-by-point.

Pope-Hennessy contrasts the splendour of the rendering of Strada's fur mantle and satin sleeves with the sitter's features: 'they are petty, and are stamped with guile and a particularly unattractive sort of eagerness'. Members of the jury, please look at the picture and the detail reproduced and ask yourself whether you really would have interpreted the sitter's face in that way if you had not been told to do so by the learned counsel for the prosecution? The
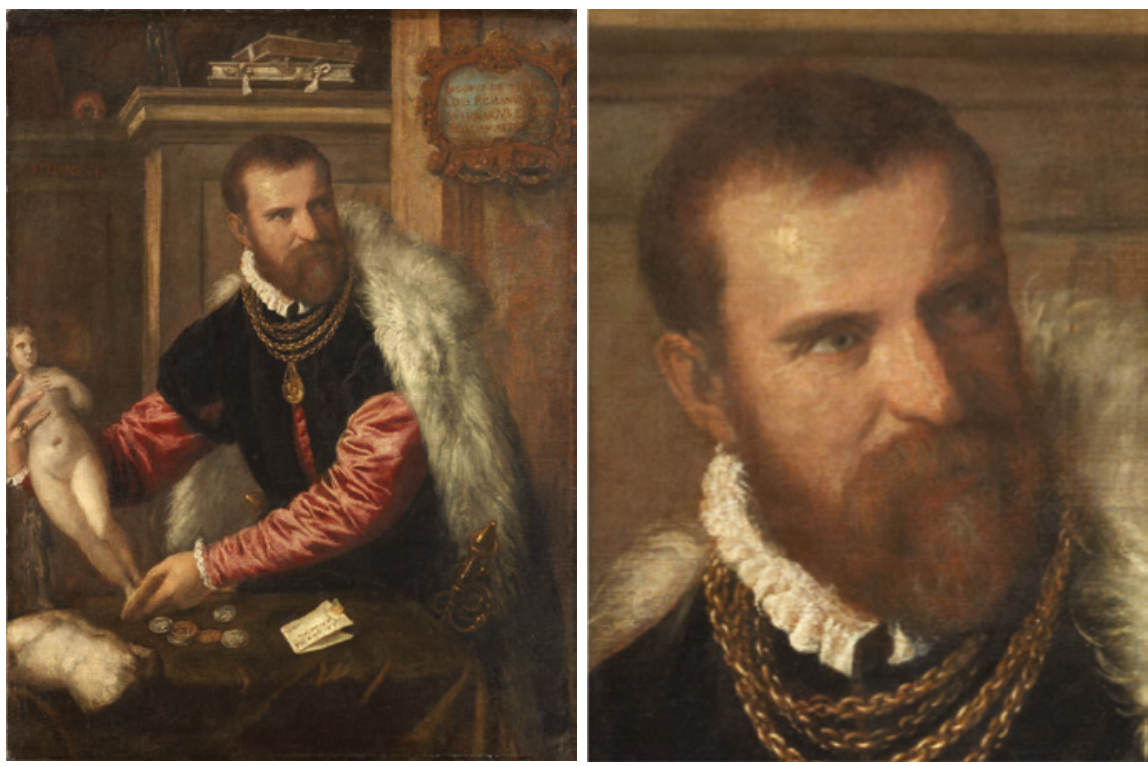

FIGURES 16.5-16.6 Titian, Portrait of Jacopo Strada and a detail of the face. 
modest psychological experiment I have related in my introductory chapter strongly suggests that you would not. An even more forceful argument is that Titian appears to have painted Strada very much as he actually looked like, witness the description of Strada's features circulated at the time by the Holy Office - the counsel for the persecution of heretics - which even included details such as the individual grey hairs in his reddish beard. To conclude that these features are 'petty' is in itself an interpretation: I, for one, do not see it. But to deduce the character traits of their owner from them is an argument reminiscent of Kaspar Lavater's and Cesare Lombroso's long discarded physiognomic theories.

'In the painting Strada is shown bending obsequiously across a table' says Pope-Hennessy, 'holding a marble statuette which he is displaying deferentially to some patron on the right'. Is it a coincidence that he chooses terms with negative connotations, while he might have chosen positive terms such as 'courteous' and 'respectful'? The terms are chosen because they relate to the 'capacity for flattery' which he attributes to Strada. Now doubtless Strada was as capable of saying and writing flattering things to his patrons as any humanist scholar or artist, which was often a dire necessity. However, there is little evidence that Strada was more 'obsequious' than other scholars and artists of his generation. On the contrary, there is abundant evidence that he was not. Strada's own letters to princes, even to the Emperor himself, are courteous and contain the habitual courtesy phrases and baciamani; but they are also very assured in tone and never humble, never in fact 'obsequious', not even when he had good reason, for instance in the letter thanking Guglielmo Gonzaga for the benefice conferred on his son Paolo. ${ }^{49}$ The assurance with which some years later he asked the Duke himself to arrange for someone to make documentary drawings of Mantua monuments is quite unusual - the more so in that the Duke appears to have actually done so..$^{50}$ Such assurance could evolve into obstinacy even with Hans Jakob Fugger, his first patron, to whom he probably owned much of his prosperity, and who remained a close associate. In a letter to Nicolò Stopio Fugger discusses Strada's waywardness:

49 Doc. 1568-12-28. Strada uses the thank-you letter also as an advertisement of his Musaeum, his potential services and his position at the Imperial court. It is instructive to compare Strada's letter to Archduke Ferdinand in December 1556 (Doc. 1556-12-22) with those written by Paul Pfinzing in the same affair (Doc. 1557-01-26): the self-abasement of Pfinzing, a Nuremburg patrician and secretary and diplomat in the service of Charles V and Philip II, can only be partially explained by German custom: Wenzel Jamnitzer's letters to the Archduke, again in the same affair (Docs. 1556-12-22 and 1557-01-27), are robust, self-confident and matter-of-fact in tone.

Doc. 1577-10-04; cf. above, Ch. 13.8.2. 
$<\ldots>$ as to Strada, is seems he behaves as usual, and if he was not so secretive, and instead showed himself more friendly, he would increase his stature; for in truth, one wonders what he would be if he was not more expert in antiquities than anyone else; for the rest it seems he is rather insufferable to those who do not do exactly as he wants. Enough; he is gone to Vienna, and has left me a note which I wish had been kinder and more friendly; but this is the way he is made, and he loses more than he gains by it $<\ldots$. .

Fugger continues to tell Stopio that Duke Albrecht intends to use Strada's concept and designs for the new Antiquarium, adding, with a touch of irony, 'if at least he will deign to come here.51 'Obsequious' is not exactly the qualification which I would apply to someone displaying such behaviour. Yet for all his reservations, Fugger squarely chose Strada's side when he became aware of Stopio's own incompetence in antiquarian matters, and realized how viciously he had attempted to blacken Strada's name. He would remain on good terms with Strada until his death in 1575, the same year that Strada published his enthusiast account of Fugger's contribution to the Munich collections-an account which again does not sound 'obsequious', but rather reflects Strada's own happy memories of - and pride in — the share he had been given in the realisation of Fugger's and Duke Albrecht's ambitions. ${ }^{52}$

Stopio himself certainly did not accuse Strada of undue servility towards his patrons: 'in fact his arrogance is insufferable: if he talks about the Emperor or the princes, it seems that they are staying with him, instead of he staying with them'. If his descriptions have any kernel of truth in them, they indicate that Strada took a lot of trouble to present himself as a nobleman and courtier, and as an independent agent, rather than as a servant:

$<\ldots>$ he went about here $<\ldots>$ in scarlet hose, with his son as a page and accompanied by three or four of these appraisers, so that he looked like a nobleman with his suite $<\ldots>$.

$5^{1}$ Copy of Fugger's letter to Stopio, Ingolstadt 25 August 1568, BHStA- $L A 485^{2}$, fol. 165-166: < $<\ldots>$ Quanto al Strada me pare che luy tenga al solito suo, et se non si simulse tanto, anzi se dimostrasse piu amorevole, si faria maggior assai di quello che è, che in verita si [puo ?] dir quanto se ne vagli esso se non intende circa l'antiquaglie quant' un altro; del resto pare che sia assai insuportabile a chi non fa tutto a modo suo; basta, egli è ito a Vienna et mi ha lassiato una sua che voria fusse piu dolce, et amorevole; ma egli è pur fatto cosí, et con questo perdene $\mathrm{p}[\mathrm{er}] \mathrm{de}$ assai piu che non guadagna. $<\ldots>\mathrm{S}$. Ecc. è deliberata di fabricare una stanza $\mathrm{p}[\mathrm{er}]$ le sui antiquaglie, et circa l'ordinare vuol usare il disegno et parere $\mathrm{d}[\mathrm{e}] \mathrm{l}$ Strada, se pero si vorra degnare di venir in qua $<\ldots>$. 
They also confirm Strada's wilful attitude to others:

Strada is not suitable to negotiate here [in Venice], because he is too presumptuous and choleric, he immediately wants to pronounce a judgment in his own way, and will sustain it [against all others] and then departs in a huff. 53

When Fugger asks Stopio what he knows about Strada's flight for the Inquisition from Mantua, Stopio replies that out of respect for the Emperor the Signoria would not let Strada be molested by the Holy Office in Venice,

$<\ldots>$ even though from his talk I have not understood that he is an enemy of Rome, except that he is very free in his reasoning, and that when he gets excited he has no respect for anyone whomsoever $<\ldots . . .^{54}$

Reading these notes, some of which seem to be true to nature, Strada's later conflict with his son Ottavio becomes more comprehensible. All the same, in his letters to Fugger Stopio was sometimes rather economical with the truth: in fact he does everything he can to discredit his rival. The tone of his letters - the content of which he begs Fugger to keep hidden from Strada-indicates that his criticism was motivated not just by mercantile competition. Stopio is choking in his envy of Strada - whom he had known in less august circumstances fifteen years earlier-because of his position as a nobleman and courtier, and as the wealthy agent of the Emperor as well as of a major prince and of Stopio's own principal patron. And he did not want to believe Fugger's assertion that Strada was reputed to be 'one of the first and most learned antiquaries of Europe':

53 Stopio to Fugger, Venice 7 March 1568, BHStA-LA 4852, f. 157/149: '<...>in effetto la sua arrogantia è insupportabile, che quando parla dell'Imperatore o delli principi, par che loro stanno con lui, et non lui con loro'; idem, Venice, 16 januari 1568: '<...> > certo in general sento da tutti ch'il procedere del Strada non serve per negociare qui con costoro, perchè è troppo presontuoso et colerico, subito vuol fare il giudicio a suo modo, et sustenarlo, et con colera se ne parte $<\ldots>$ Andava qui per la terra $<\ldots>$ con le calze di scarlato, col figliuolo per paggio et 3. 04 di questi suoi sanzali appresso che pareva un conte et cavalliere, ma prometto a V.S. che questa terra non vuol tal procedere $<$... >'.

54 Stopio to Fugger, Venice 5 Octobre 1567 , BHStA- LA 4852, ff. 75/69: ‘[Strada] venne poi di longo a Ven<eti $>$ a, over per rispetto de l'Imp<erato $>$ re non li haveriano lasciato dare molestia; benche non ho inteso al suo parlare ch'l sia contrario alle cose Romane, se non ch'l è molto libero di ragionare, et intrando in colera non ha respetto alcuna sia di chi essere si voglia $<\ldots>$. 
I would be astounded if he would have studied so much in 12 or 15 years; he has well studied how to serve his own interests, and how to deceive in places where he has found good-natured, credulous and sympathetic people, God forgive him $<\ldots>^{55}$

It is this same sentiment-or resentment-which Stopio later ascribed to Titian in an often quoted passage describing Strada's dealings with Titian: 'two gluttons at one plate', as Stopio has it. ${ }^{56}$ In view of Strada's occasionally extreme behaviour, it is perfectly possible that Titian had mixed feelings about Strada, and expressed his reservations to some of his friends. But one should note that Stopio only reported this at second hand, and that he only reported what he had wished to hear; he would have ignored anything positive Titian may also have said about Strada. The very fact that Titian conceded to paint Strada's portrait — his very last - and that he presented him with another painting apparently as a gift, and engaged in other business transactions with him, are sufficient indication that he in fact must have respected and trusted Strada.

Pope-Hennessy's discussion of the portrait follows Stopio's suggestion that he deceived his patrons for financial gain, laying it on thickly, using words as 'duplicity' and 'guile'. There can be no doubt that Strada expected to make money by his transactions, as any merchant would have. It is also true that there appears to have been a rumour that he made Duke Albrecht pay prices that were too high. This rumour was probably started by Stopio, who in his letters to Fugger constantly claimed that he could have bought the same or similar things for less money. But the shipments he himself did provide turned out to be very

55 Stopio to Fugger, Venice 8 June 1567 , BHStA-LA 4852, f. 32/26: '<... > Tutto questo dico sol perche Vostra Signoria mi scrisse già, che'l e tenuto per uno de primi antiquarii intelligenti di Europa. Mi maravegliaro se in 12015 anni haveva studiato tanto, l'ha ben studiato ch'l ha saputo fare il fatto suo, et cacciare carotte in luoco dove ha trovato le persone di buona natura creduli et amorevoli, Iddio li perdoni $<\ldots>$.

$5^{6}$ Stopio to Fugger, Venice 29 February 1568, BHStA-LA 4852, f. 153/145: 'Il Titiano et lui sono doi giotti a un tagliero: Strada li fa fare il suo ritratto, ma vi stara sopra ben ancora un anno, et se in questo mezzo il Strada non li farà li servicij che desidera, non l'havera mai compito: già S. Titiano ha affectato per havere ò in dono ò per li suoi dinari una fodra di gibbelini, et per questo vorrebbe mandare non so che a l'Imperatore; il Strada li da speranze per cavarli il ritratto dalle mani, sed surdo narrat fabellam. Ma ben è da ridere che l'laltro giorno dimandando un gentilhuomo molto intrinseco di S. Titiano, et mio amicissimo, che cosa li pareva del Strada; rispose subito il S. Titiano, il Strada è uno delli solenni ignoranti che si possa trovare, lui non sa niente, ma bisogna haver ventura, et sapersi accomodare alle nature delle persone, come ha fatto il Strada in Alemagna, dove caccia tante carotte a quelli Todeschi quanto si può imaginare, et loro come reali di natura non conoscono la dopiezza di questo galant'huomo. Queste furono le parole di S. Titiano, hora V.S. consideri in che conto l'habia ancora lui.' 
bad buys, showing Fugger that Stopio possessed neither the necessary expertise, nor any comprehension of the ambitions in Munich. ${ }^{57}$ And though Strada did make the Duke pay high prices, those were the prices he had to pay to the owners from whom he bought. As an agent of the Duke of Bavaria he felt it due to exercise by proxy such princely virtues as 'magnificence' and 'liberality': it is no coincidence that in his jubilant description of the Munich collections Strada stressed the 'great pains and expense of money' it had cost to acquire Fugger's coins and other antiquities, and that the Duke had spent 'thousands of ducats' in the acquisition of the Loredan collection. ${ }^{58}$ Strada would be the last person to be proud of having bought something at a bargain. About the quality of Strada's acquisitions his patrons never complained: Fugger himself made quite clear to Stopio that he was still quite content with the antiquities Strada had bought for him in Rome in the 1550s, and though few of the objects acquired by Strada for Munich can be identified with certainty, the holdings of the Munich Antiquarium give some impression of its relative quality.

Thus there are no concrete indications that Strada had ever in any way defrauded his patrons: in fact for over two decades Fugger and afterwards the Duke of Bavaria trusted him sufficiently to buy huge quantities of ancient coins, statues and other antiquities, jewels, books, manuscripts and contemporary works art from him or through his mediation. Likewise none of his other patrons ever seem to have doubted his bona-fides. In view of Strada's activities, his interests, his ambitions as sketched in this study, I think it is legitimate to conclude that Pope-Hennessy's and-in his wake-Agosto Gentili's negative interpretations of the Titian portrait are unwarranted and do justice neither to its sitter nor to its painter's intentions.

L.D. - Gotha, 5 March 2018

57 Early in 1574 Strada heard from an unnamed gentleman that the Duke had complained about him ('che Sua Excellenza si duolga di me, et che mi tenghi in poca sua gratia'), but without being told what could have caused that, except a suspicion that Strada would have kept objects belonging to the Duke for himself. In a letter to Fugger which sounds sincere (Doc. 1574-03-01) Strada asks him to confirm how carefully and honestly he had negotiated in the Duke's business, which implies that he must have known that some rumours as to his dealing were circulating. Examples of Stopio's bad buys are discussed in Von Busch 1973, pp. 141-142 and 151-152.

Caesar $1575, \mathrm{f}^{*} 4 \mathrm{r} \cdot-{ }^{*}{ }^{*} \mathrm{v}$. 